\title{
Individual-based modeling of feeding ecology and prey selection of larval cod on Georges Bank
}

\author{
Trond Kristiansen ${ }^{1,4, *}$, R. Gregory Lough ${ }^{2}$, Francisco E. Werner ${ }^{1,5}$, \\ Elisabeth A. Broughton ${ }^{2}$, Larry J. Buckley ${ }^{3}$ \\ ${ }^{1}$ Marine Sciences Department, University of North Carolina, Chapel Hill, North Carolina 27599-3300, USA \\ ${ }^{2}$ Northeast Fisheries Science Center, NMFS, NOAA, Woods Hole, Massachusetts 02543, USA \\ ${ }^{3}$ University of Rhode Island/NOAA CMER Program, Graduate School of Oceanography, Narragansett, Rhode Island 02882, USA \\ ${ }^{4}$ Present address: Institute of Marine Research, PO Box 1870 Nordnes, 5817 Bergen, Norway \\ ${ }^{5}$ Present address: Institute of Marine and Coastal Sciences, Rutgers University, New Brunswick, New Jersey, United States
}

\begin{abstract}
Understanding larval fish survival dynamics is essential to determining variability in future adult population structure. Realistic modeling of larval fish feeding ecology depends on incorporating both the biotic and abiotic conditions that affect predator-prey interactions. We used an individual-based model (IBM) to test which variables drive Atlantic larval cod Gadus morhua feeding preferences. The IBM included a bioenergetics component that incorporated metabolic parameters and growth and a mechanistic prey selection component that depended on larval development and behavior, prey size and behavior, depth, light, and physical oceanographic conditions. We applied our model to Georges Bank and incorporated high-resolution field data on environmental conditions and prey abundance to analyze larval cod feeding ecology. Based on simulated selectivity indices, we found that cod prey selection was determined by differential encounter of prey due to the abundance of suitably sized prey, their visibility, and larval cod ability to capture these prey items. The model suggested that Pseudocalanus spp. were the dominant prey species for larval cod because of their abundance in the water column and their large image area. Centropages spp. were also modeled to be an important part of larval diet, but no copepodite stages of this taxon were found in gut samples. Lack of Centropages spp. in the gut samples indicated that they are more elusive in their behavior than Pseudocalanus spp. Overall our results suggest larval cod feeding ecology on Georges Bank is a consequence of the physical and biological conditions rather than active prey selection.
\end{abstract}

KEY WORDS: Feeding ecology $\cdot$ Individual-based model $\cdot$ Cod $\cdot$ Larval fish $\cdot$ Georges Bank $\cdot$ Gadus morhua Prey selection

\section{INTRODUCTION}

Fish year-class strength is strongly dependent on growth and survival during larval stages, when mortality is greatest (Houde 1987, Sundby et al. 1989). Growth and survival are generally related to abiotic factors such as temperature, light, and turbulence, and on the ability of the larvae to encounter and capture prey items (Campana et al. 1989, Chambers \& Trippel 1997, Fiksen \& MacKenzie 2002, Folkvord 2005). In addition, biotic factors such as functional constraints on larval swimming capabilities (Peck et al. 2006) can limit the size of potential prey. As larvae develop, they are able to pursue and capture larger prey (Kane 1984, Puvanendran et al. 2004) and sustain their increasing energy demands (Pope et al. 1994). Consequently, areas with high prey densities of different prey sizes provide ideal conditions for rapid growth and potentially increased fish survival (Miller et al. 1988, Hare \& Cowen 1997), and thereby stronger year-classes (Ottersen \& Loeng 2000).

A key component in determining how larval cod select their prey is to understand how the predatorprey encounter rate is controlled by light. Aquatic environments are shaped by the scattering and absorption of light. Light intensity changes with depth 
and throughout the day, and feeding may be constrained at low light intensities or in turbid and murky waters (Aksnes \& Utne 1997). For visual feeders, larger prey will appear more visible in the water column, and, assuming equal concentrations, they will be more frequently encountered than smaller prey if they are homogenously distributed (Eggers 1977). Consequently, prey that are easily perceived because of their size and/or contrast are more likely to be found in the stomach of predatory fish simply because they are more frequently encountered. Luo et al. (1996) defined this increase in encounter as 'differential random encounter' (hereafter differential encounter), an effect of prey visibility and abundance. Still, selectivity indices will perhaps wrongly determine this increase in encounter as active selection.

We used an individual-based model (IBM) (Kristiansen et al. 2007) to analyze what regulates the larval preference for Pseudocalanus spp. (Kane 1984, 2007). Since the 1990s IBMs have been used successfully in the study of marine organisms and population dynamics (see the review by Werner et al. 2001 and Miller 2007) and have increased in complexity during the last few years (Grimm \& Railsback 2005). The IBM presented here is identical to the IBM published by Kristiansen et al. (2007), however, with a new component for vertical behavior. The IBM included a mechanistic feeding component that enabled explicit modeling of larval encounter, pursuit, and capture success of prey items. Observations of the vertical distribution of zooplankton, as well as gut samples of larval cod (Lough et al. 2005), allowed direct comparisons between observed and modeled diets. Based on our model results and field data, we explored the importance of total prey abundance, as well as how vertical distribution of prey stages affected the growth and prey selection of larval cod.

We hypothesized that the apparent preference of larval cod for the prey Pseudocalanus spp. on Georges Bank resulted from differential encounter (Eggers 1977, Holzman \& Genin 2005), combined with the ability of the larvae to capture this species. In this context, differential encounter was a perception-based preference for prey species based on their abundance and visibility (image area) in the water column. Therefore, the physical and biological characteristics of prey, predator, and the environment determined differential encounter, whereas active selection was defined as particular prey items being pursued while others were ignored. We also tested the model by examining the relationship between observed and modeled growth rates and diet selection for larval cod in 2 different years. Combined, this approach may help us understand why larval cod on Georges Bank feed predominantly on Pseudocalanus spp.

\section{MATERIALS AND METHODS}

Our model description follows the overview, design concepts, and details (ODD) protocol suggested as a standard by Grimm et al. (2006).

Purpose. Our IBM simulated the foraging ecology in the early life history of larval Atlantic cod Gadus morhua. The IBM included complex components for feeding, growth, and behavior of individual larval and juvenile cod. Individual interactions between predator and prey items were modeled mechanistically and included the encounter, approach (pursuit), and capture success. The model also accounted for the physical and biological properties of the system that affected the developing larva's feeding success. Larval visual abilities (determined through light levels), prey abundance, and prey size all affect feeding success and were incorporated into the model. This approach ensured that all the underlying processes that are believed to be important factors in the feeding of larval fish were included. The processes were formulated and parameterized from laboratory experiments conducted on larval cod (Fiksen et al. 2002). Our main purpose was to explore how physical and biological properties of the habitat determined larval cod prey selection.

State variables and scales. Individual cod larvae varied in size from 5 to $15 \mathrm{~mm}$ and were simulated as part of the habitat observed on Georges Bank from 22 to 27 May in 1993 and 1994 (Fig. 1). The depth of the water column was $70 \mathrm{~m}$, divided into $1 \mathrm{~m}$ discrete depth bins, between which the individual larvae were allowed to migrate vertically. The environment was described by observations of temperature, zooplankton abundance and distribution, modeled light, turbulence, and predators. Individual larval fish were described by their dynamic state variables (length, weight, gut fullness). Zooplankton was distributed throughout the water column in $1 \mathrm{~m}$ depth bins, based on observations of abundance, species, and size. The number of predators was assumed to be constant in depth and time; however, vertebrate and invertebrate predation pressure dynamically changed as a function of light level and larval size.

Process overview and scheduling. The interactions between the environment and the individuals were determined through sub-models, which were estimated sequentially at every time step in the model. One submodel, the mechanistic feeding component of the IBM, simulated the details of the foraging behavior sequentially: prey encounter, approach, capture, and ingestion. Larval foraging is visual and therefore dependent on the light level at the time of the day (for the given latitude and day of the year) and the given depth position. Each of the foraging steps was repeated for each of 4 prey taxa (Calanus finmarchicus, Pseudocalanus 
Fig. 1. Map of Georges Bank. O: sampling sites in May $1993 ; \Delta$ : sampling sites in May 1994. Main spawning of Atlantic cod Gadus morhua occurs in February to April around the Northeast Channel, and larvae and eggs drift passively with the ocean circulation southwards, along the slope of the bank. Larvae reach the western end of Georges Bank by June to July, and enter the summer and autumn nursery habitats on the Georges Bank plateau. Depth contours (m) shown

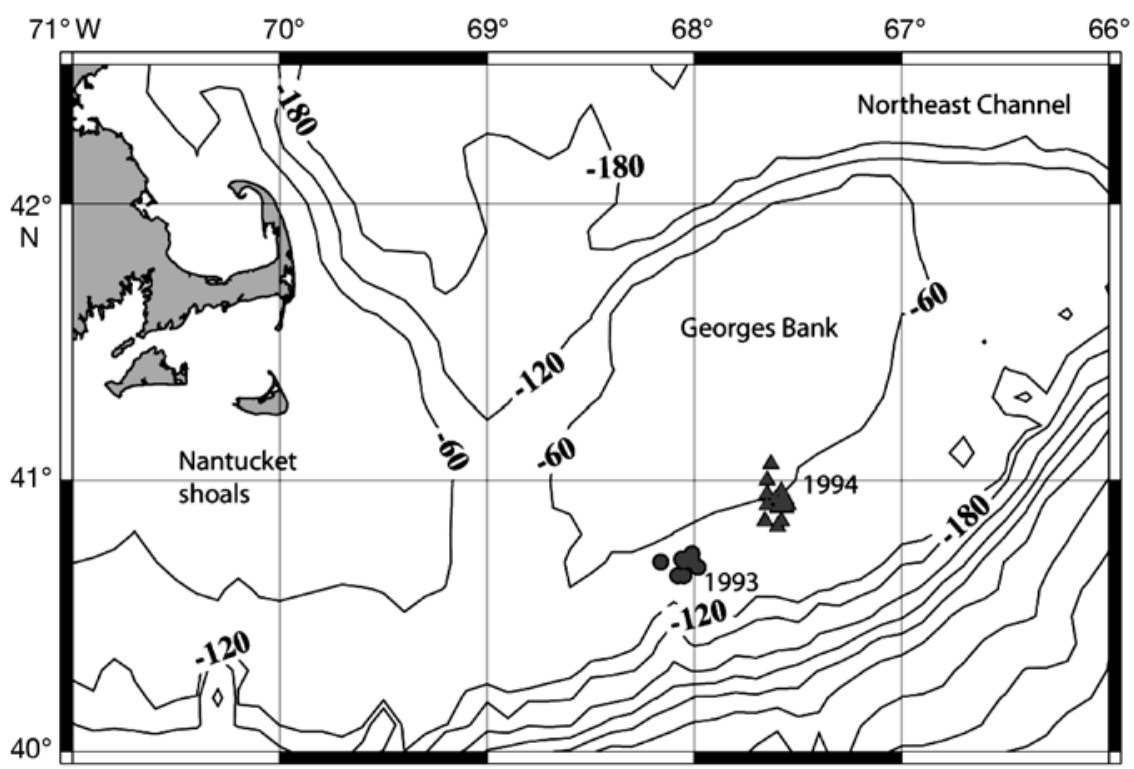

spp., Oithona spp., and Centropages spp.), for each prey stage (6 nauplii, 5 copepodites, 2 adult). The total ingested biomass per time step was stored in the stomach. Metabolism and growth were calculated in their respective sub-models based on the calculated total ingested biomass. Growth was food limited if the total biomass in the stomach was insufficient to sustain maximum temperature-dependent growth rates (Kristiansen et al. 2007); otherwise, only temperature restricted the maximum growth rate (Folkvord 2005). When total growth had been estimated, the larva was moved to its next depth position following a vertical behavioral rule. The steps in the feeding and growth processes were then repeated at the new depth position for the next time step.

The combination of a mechanistic foraging and a behavioral component allowed for dynamic exploration of how fish feeding was controlled by the properties of the local habitat.

Design concepts. Emergence: Information on the population structure, depth distribution, and feeding and growth patterns emerged from the dynamics and behavior of the individuals. This included the diel vertical migration patterns resulting from trade-offs between feeding and risk of predation.

Sensing: Individuals were able to sense their stomach fullness, which was a driver for their vertical behavior. Individuals were also able to sense ('know') the ingestion and mortality rates at a range of depths above and below their current position. The above and below depth ranges were limited by the distance the larva was able to swim at routine swimming speed within 1 time step.

Interaction: Individual fish were subject to densityindependent processes, while density dependency was not included. Fish feeding did not have a feedback on the prey concentration.

Stochasticity: The escape jump angle of prey when approached by a predator was implemented as a random angle in the range of $\pm 30^{\circ}$ away from the fish gape.

Observations: All state variables of fish were recorded for every time step, together with information on larval temporal and spatial distribution in the water column.

Initialization. All individuals were initialized with a $10 \%$ full stomach, at standard lengths (SL) of $5 \mathrm{~mm}$ $(86 \mu \mathrm{g}), 7 \mathrm{~mm}(285 \mu \mathrm{g}), 9 \mathrm{~mm}(705 \mu \mathrm{g})$, and $11 \mathrm{~mm}$ $(1450 \mu \mathrm{g})$ (all weights given as dry weight). For both 1993 and 1994, individuals were modeled from 22 May at 13:00 h local time to 27 May at 24:00 h. Two main types of model runs were performed.

In the first type, individual larvae were fixed in the water column at $1 \mathrm{~m}$ depth intervals, and growth rates and stomach contents were recorded for $5 \mathrm{~d}$. The result was a static image of the growth rates with depth and time. This static image was combined with observations of the weighted mean depth (WMD) for 3 sizeclasses of cod (2 to 5, 6 to 8, 9 to $13 \mathrm{~mm}$ ) (Lough et al. 2005). The modeled cod growth rates in the water column were then weighted by the observed larval sizeclass ( 2 to 5,6 to 8,9 to $13 \mathrm{~mm}$ ) distribution with depth, and defined as the WMD growth rates.

The second type of model runs allowed us to explore the modeled feeding and growth rates of larval cod of various sizes that exhibited dynamic vertical behavior. Larvae were initialized at $15 \mathrm{~m}$ depth and simulated $24 \mathrm{~h}$ forward in time before any results were recorded. Simulated growth and stomach contents were recorded for a period of $5 \mathrm{~d}$ for vertically migrating larvae under 
3 different scenarios. For Scenario 1, we modeled growth and ingestion of individuals that optimized their vertical position by trading off between local ingestion and mortality rate within a $1 \mathrm{~h}$ swimming range (Fiksen et al. 2007, Vikebø et al. 2007). The optimized trajectory in the water column was designated OPT. For Scenario 2 , we assumed unlimited food supply (temperaturedependent growth, TDG) for individuals that followed the ingestion OPT. Finally, for Scenario 3, we assumed that individuals did not feed on Centropages spp. (NoC), but still followed the ingestion OPT. All of the model runs were performed with the presence of predators turned on and off to allow us to explore their effect on larval vertical behavior, feeding behavior, and growth rates.

Input. Prey, temperature, and turbulence measurements: The larval habitat was modeled using the temperature (Fig. 2), turbulence, and zooplankton data (Fig. 3) described by Lough et al. (2005), and modeled estimates of light as a function of day of the year, latitude, and depth (Skartveit et al. 1998). Temperature,

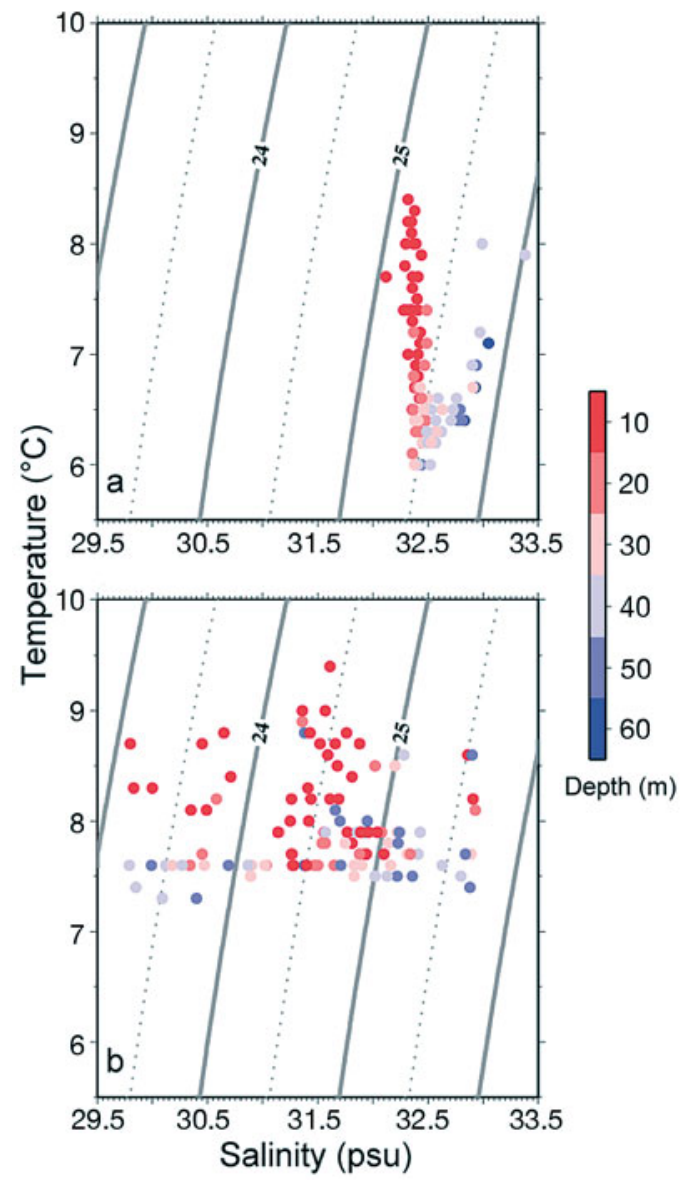

Fig. 2. Temperature $\left({ }^{\circ} \mathrm{C}\right)$ and salinity (psu) plot for May (a) 1993 and (b) 1994. Density contours $\left(\sigma_{t}\right)$ are shown as grey lines. Sampling depths $(\mathrm{m})$ for temperature and salinity measurements are indicated by color (see scale) turbulence, and prey abundance distribution data are from 2 time periods: 22 to 27 May 1993 and 22 to 27 May 1994. In 1993, temperature ranged from 5.5 to $8.5^{\circ} \mathrm{C}$ (Fig. 2), while, in 1994, temperature ranged from 7.2 to $9.5^{\circ} \mathrm{C}$. On average, the temperature was $1^{\circ} \mathrm{C}$ higher in May 1994. In both years, a cohort of larval cod was tracked for $5 \mathrm{~d}$ using a drifter deployed at $13 \mathrm{~m}$ depth (Lough et al. 2005). Since directed horizontal movements of larval fish are much less forceful than the prevailing horizontal currents, we assumed that biological and physical sampling along the trajectory of the drifter represented the habitat experienced by the cohort of larvae. The initial location of the 1993 cohort was $40^{\circ} 43.0^{\prime} \mathrm{N}, 68^{\circ} 3.0^{\prime} \mathrm{W}$ (Fig. 1, circles), and that of the 1994 cohort was $40^{\circ} 55.0^{\prime} \mathrm{N}, 67^{\circ} 35.0^{\prime} \mathrm{W}$ (Fig. 1, triangles). For both years, the drifter was located in stratified water, and, consequently, all temperature (Fig. 2) and zooplankton (Fig. 3) data were from stratified sites. Zooplankton was sampled every $10 \mathrm{~m}$ using a $0.25 \mathrm{~m}^{2}$ MOCNESS, with $64 \mu \mathrm{m}$ mesh nets. Calanus finmarchicus, Pseudocalanus spp., Oithona spp., and Centropages spp. were sorted into 6 naupliar, 5 copepodite, and adult female and male stages. The model included the 4 most common taxa found in the gut contents of larval and juvenile cod on Georges Bank. Other species may be found, but, in general, they would amount to $<5 \%$ of the observed gut contents and, therefore, would not likely influence the present study. RNA:DNA ratios based on growth rates for various size-classes of larval cod were taken from Lough et al. (2005), and they provided data for comparison between observed and modeled growth rates. Turbulence was generated from a 1-dimensional model, initialized by the observed wind conditions and hydrographic properties, and the $\mathrm{M}_{2}$ tide (Naimie 1996). May 1994 had almost twice the total zooplankton biomass of 1993 (for the 4 taxa considered); however, the largest increase in biomass was found for adult stages of $C$. finmarchicus. In both years, $C$. finmarchicus (Fig. 3a,b) was located primarily in the upper $30 \mathrm{~m}$, while Pseudocalanus spp. (Fig. 3c,d) biomass increased below $20 \mathrm{~m}$, which was the depth of the thermocline. Pseudocalanus spp. biomass was 30\% greater in May 1994, and most of its biomass occurred between 50 and $70 \mathrm{~m}$ depth. Oithona spp. (Fig. 3e, f) did not contribute significantly to the total biomass $(3.1 \%$ in 1993 and $9.2 \%$ in 1994) because of their small size. Oithona spp. were mainly found in the upper $10 \mathrm{~m}$. Centropages spp. (Fig. 3g,h) biomass was $43 \%$ of Pseudocalanus spp. biomass for both May 1993 and 1994, with maximum biomass located in the upper $30 \mathrm{~m}$.

Temperature and salinity were concurrently sampled at $4 \mathrm{~s}$ intervals. Temperature data were further averaged for every $1 \mathrm{~m}$ and interpolated in time at $1 \mathrm{~h}$ resolution and incorporated into the IBM (Fig. 2). Zoo- 


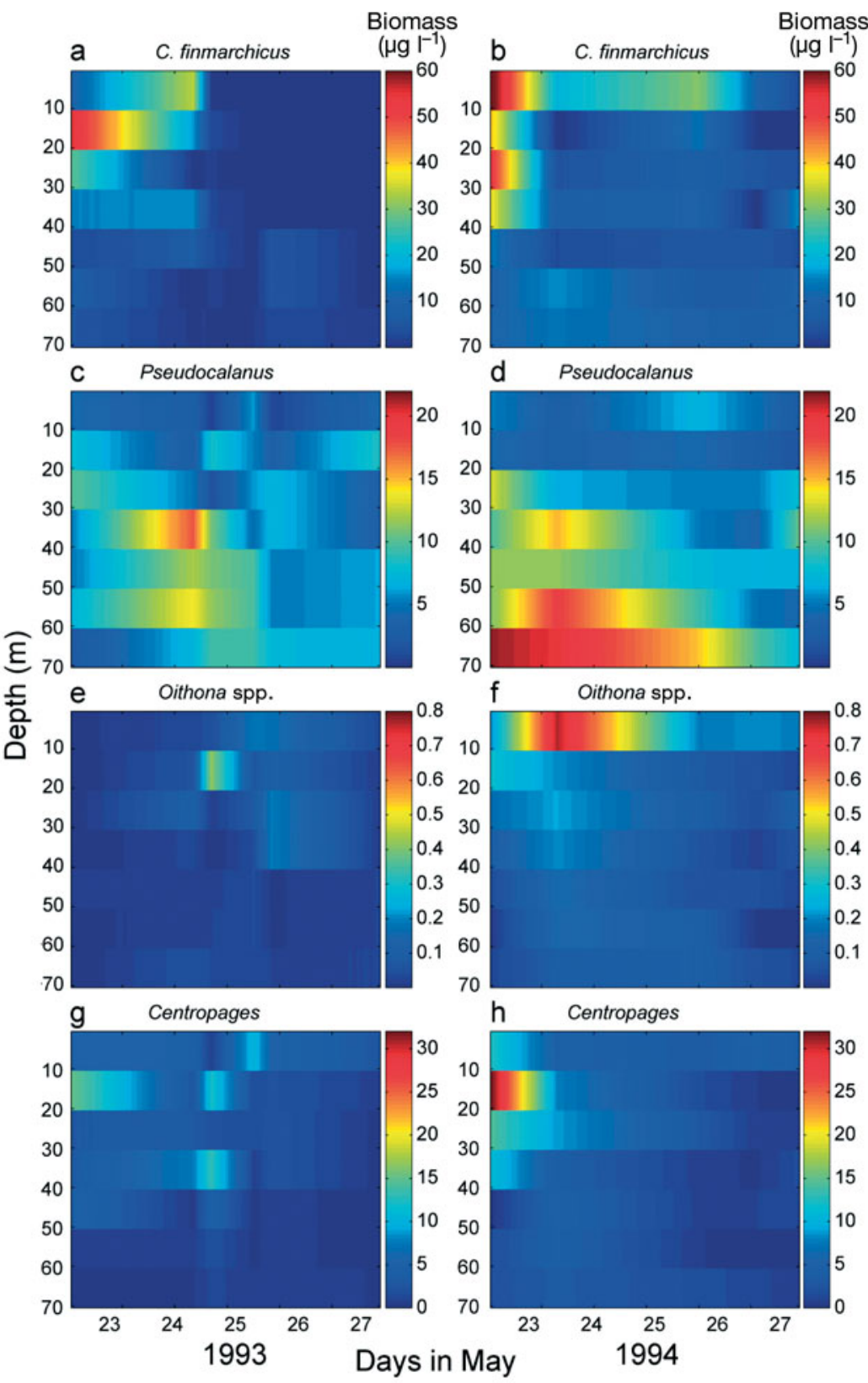

Fig. 3. Zooplankton biomass $\left(\mu \mathrm{g}^{-1}\right)$ distribution sampled in May $(\mathrm{a}, \mathrm{c}, \mathrm{e}, \mathrm{g}) 1993$ and $(\mathrm{b}, \mathrm{d}, \mathrm{f}, \mathrm{h}) 1994$ from Lough et al. (2005) (see Fig. 1 for positions of sampling sites) for the 4 species (a,b) Calanus finmarchicus, (c,d) Pseudocalanus spp., (e,f) Oithona spp., and $(\mathrm{g}, \mathrm{h})$ Centropages spp.

Sub-models. Feeding model: A full description of the IBM used in this analysis can be found in Fiksen \& MacKenzie (2002) and Kristiansen et al. (2007). The feeding component of the IBM consists of 3 sequential steps, which were estimated at each time step $(1 \mathrm{~h})$ : (1) prey encounter, (2) prey approach/pursuit, and (3) capture.

(1) Larval cod are pause-travel visual predators (Hunter 1981, O'Brien et al. 1989), and prey encounter therefore depends on the larva's ability to perceive prey (Aksnes \& Utne 1997) at a given light level. Light intensity varies with time of Day $h$ and Depth $z$, and is a function of the surface light and the diffuse light attenuation (water clarity). Surface light was calculated according to time of the day, latitude $\left(\sim 41^{\circ} \mathrm{N}\right)$, and day of the year (here 22 to 27 May). Light was used as input to the foraging component to estimate a larva's visual perception of a prey item for the given depth, attenuation coefficient (clarity of water), beam attenuation coefficient (the loss of light between predator and prey at the same depth level over their separation distance), prey contrast, and image area. Turbulence may increase the number of prey swept into the perception area of the larvae (Fiksen \& MacKenzie 2002), thereby increasing the encounter rate. Prey may also swim into the larva's perception area (MacKenzie \& Kiørboe 1995) during pause and search.

(2) If a prey item is encountered the larva needs to approach the prey carefully and assume an attack position. The pursuit is successful if the larva can swim to its attack position at a speed that does not create pressure gradients in the water that exceed the prey's alarm threshold (Kiørboe \& MacKenzie 1995). In our IBM, larvae were always allowed to swim below the threshold value, but the distance from the larva to the prey (distance of perception) had to be traveled within $10 \mathrm{~s}$ (average value from laboratory experiments; see Fiksen \& MacKenzie 2002) or else the approach failed (e.g. if a small larva detects a

plankton data were interpolated in time and used as input to the IBM (Fig. 3).

The depth distribution of larval cod was sampled every $10 \mathrm{~m}$ and every $6 \mathrm{~h}$ using a $1 \mathrm{~m}^{2}$ MOCNESS, with nine $333 \mu \mathrm{m}$ mesh nets. Vertical distributions of cod (numbers $100 \mathrm{~m}^{-3}$ ) were presented as mean vertical profiles over the entire sampling period by Lough et al. (2005), while, in the present study, the in situ values were used to analyze the variability of larval depth distribution with time. large prey, the distance is too large to travel in $10 \mathrm{~s}$ ). If the turbulence level is high, prey may be swept out of the perception area of the larva (Fiksen \& MacKenzie 2002), resulting in an unsuccessful approach (MacKenzie \& Kiørboe 2000). Prey behavior was restricted to jump escape speeds, which are proportional to prey length. The handling time spent on the unsuccessful approaches was included in total handling time (Fiksen \& MacKenzie 2002). If the pursuit was successful, the larva was able to reach an attack position. 
(3) The probability of capture success was determined from the relative ratio of the attack speed of the predator, the escape speed and jump angle of the prey, and the mouth size of the larva (the width of the prey cannot be larger than the gape size of the larva for it to be able to swallow its prey) (Caparroy et al. 2000, Fiksen \& MacKenzie 2002). If the larva made an attempt to attack, the prey responded by jumping at a random angle away from the larva. If the prey was able to reach a location outside the field of view of the larva before the larva was able to reach the prey, the prey escaped. If the prey jumped away from the larva, but still remained in the perception area of the larva, the larva could continue to attack the prey at most 3 times. The outcome of each predator-prey interaction was modeled 100 times to yield a probability of success.

Stomach and growth model: Total biomass ingested per time step $(\mathrm{d} t)$ was estimated from the encounter rate of prey items multiplied by the probability of capture, the probability of successful approach, and the weight of the prey (Kristiansen et al. 2007). This procedure was repeated for all 4 available prey taxa and all 13 stages (52 times in total), and the total ingested biomass was summed and stored in the larval gut/stomach (Kristiansen et al. 2007). For all prey items, we also estimated the time spent on foraging using Holling's disc equation (Holling 1966). The maximum amount of food ingested per time step could not exceed the stomach capacity. The routine metabolism $R=$ $57.12 \times 10^{-7} \cdot W^{0.9} \cdot \exp (0.088 \cdot T)\left(R, \mathrm{mg} \cdot \mathrm{d}^{-1}\right)$ of larval cod was parameterized according to Finn et al. (2002) and expressed by larval dry mass $(w, \mathrm{mg})$ and temperature $(T)$. Metabolism increased when the larvae were active, and we defined active metabolism as $R_{\text {active }}=$ $2.5 R$ for larval size $\mathrm{SL} \geq 5.5 \mathrm{~mm}$ and $R_{\text {active }}=1.4 R$ for larval size SL $<5.5 \mathrm{~mm}$ (Lough et al. 2005). Active metabolism ( $R_{\text {active }}$ ) was used when light was above a threshold $\left(0.01 \mu \mathrm{mol} \mathrm{s}{ }^{-1} \mathrm{~m}^{-2}\right)$. When the light level was too low for feeding (no activity), active metabolism equaled routine metabolism $\left(R_{\text {active }}=R\right)$. Growth per time step was calculated as either the temperatureand food-dependent or only the temperature-dependent (food-independent) rate. Growth was temperature dependent if the amount of biomass stored in the stomach exceeded or equaled the biomass required to grow at the maximum rate. The temperature-dependent rate (Folkvord 2005) is:

$$
\operatorname{SGR}(w, T)=a-b \ln (w)-c \ln (w)^{2}+d \ln (w)^{3}
$$

where SGR is the specific growth rate $\left(\% \mathrm{~d}^{-1}\right)$, expressed as a function of temperature $(T)$ and dry mass $(w, \mathrm{mg})$, and where $a=1.08+1.79 T, b=0.074 T$, $C=0.0965 T, d=0.01132 T$. The instantaneous growth rate $g\left(\mathrm{~d}^{-1}\right)$ is expressed through the relationship $g=$ $\ln [(\mathrm{SGR} \cdot \mathrm{d} t) / 100+1] / \mathrm{d} t$. The dry weight biomass re- quired to grow at the maximum, temperature-dependent rate is therefore:

$$
D=\left\{[\exp (g \cdot \mathrm{d} t)-1] \cdot w_{t-1}+R_{\text {active }} \cdot \mathrm{d} t\right\} / A
$$

where $A$ (dimensionless) is the assimilation efficiency (Buckley \& Dillmann 1982) and $w_{t-1}$ is the larval weight calculated at the previous time step. If the stomach content $\left(s_{t}, \mathrm{mg}\right)$ is lower than required $(D, \mathrm{mg})$ by SGR, growth is food limited and constrained by the biomass available in the stomach. The available stomach volume at the current time step $\left(s_{t}\right)$ is a function of the ingested material $(i)$, the remaining stomach content from the previous time step $\left(s_{t-1}\right)$, and the biomass extracted for growth $(D)$ :

$$
s_{t}=\mathrm{s}_{t-1}-D+i
$$

Finally, the larval weight $\left(w_{t}\right)$ at the current time step $(t)$ is given by:

$$
w_{t}= \begin{cases}w_{t-1} \cdot \exp (g \cdot \mathrm{d} t) & \text { if } D \leq s_{t} \\ s_{t} A-R_{\text {active }} \cdot \mathrm{d} t & \text { if } D>s_{t}\end{cases}
$$

Mortality. Local mortality rates were estimated from size-dependent invertebrate predation, and visual predation from a fixed density of piscivores (Fiksen et al. 2002). Invertebrate predation $\left(m_{n}, \mathrm{~h}^{-1}\right), m_{n}=0.01 \cdot \mathrm{SL}^{-1.3}$, decreased as the larvae grew (McGurk 1986) and was constant with depth and time of the day. Visual predation from piscivores changed with the light intensity and, therefore, varied throughout the day and with depth. Predation rate from fish $\left(m_{\mathrm{f}}, \mathrm{h}^{-1}\right)$ was assumed to be proportional to the visual range squared (Fiksen et al. 2002), $m_{\mathrm{f}}=0.05 P^{2}$, where $P(\mathrm{~mm})$ was the light- and prey-sizedependent perception distance of the piscivores (the coefficient 0.05 summarizes all factors such as fish density and escape probability; see Fiksen et al. 2002 for details). Total instantaneous predation rate $\left(\mathrm{h}^{-1}\right), m_{z}=m_{n}+m_{\mathrm{f}}$ was thus a function of depth, surface irradiance, and larval size. Unfortunately, we do not have any estimates of the mortality pressure during the $5 \mathrm{~d}$ that the cohort was tracked; instead we have used size- and depthdependent mortality rates.

Strategy for vertical behavior. The standard 'ruleof-thumb' for larval behavior (Gilliam \& Fraser 1987) assumes each larva uses a strategy that maximizes the ingestion rate relative to stomach fullness and that minimizes the exposure to predators and starvation mortality (Vikebø et al. 2007). We allowed the larva to move vertically in the water column and to find the depth where it was able to maximize its ingestion rate while minimizing its mortality rate. This assumed that the larva was able to sense its ingestion potential and the risk of predation that would be encountered within a $1 \mathrm{~h}$ routine swimming distance above and below its current depth location. This behavior involves a tradeoff between feeding and being eaten. Willingness to 
take a risk $\left(\pi_{i, t}\right)$ was determined by a functional relationship between larval condition (stomach fullness, larval size), local mortality $\left(m_{z}\right)$, and ingestion rates $\left(F_{z}\right.$ $\mathrm{h}^{-1}$ ), within a $1 \mathrm{~h}$ swimming distance of the larva's (i) present depth location at time $t$. The size-dependent function for routine swimming speed, $V\left(\mathrm{~mm} \mathrm{~s}^{-1}\right)$, according to Peck et al. (2006) is:

$$
V(\mathrm{SL})=0.261 \cdot\left[\mathrm{SL}^{\left.1.552 \cdot \mathrm{SL}^{(0.920-1.0)}\right)}\right]-(5.289 / \mathrm{SL})
$$

Choice of depth within swimming distance $z_{i}^{*}$, was then determined for individual $i$ by maximizing:

$$
z_{i}^{*}(t)=\max _{z}\left[\left(1-\pi_{i, t}\right) F_{z}-\pi_{i, t} m_{z \prime i}\right]
$$

where:

$$
\pi_{i, t}=\left\{\begin{array}{ll}
\left(\frac{S_{i, t}-\mathrm{STV}}{1-\mathrm{STV}}\right)^{\beta}, & S_{i, t}>\mathrm{STV} \\
0 & , S_{i, t} \leq \mathrm{STV}
\end{array}\right\}
$$

$\beta$ is equal to $5, s$ is stomach fullness, $\operatorname{STV}(\mathrm{SL})=0.3+10^{3}$. $\left(1+\mathrm{SL} \cdot \mathrm{e}^{\mathrm{SL}}\right)^{-1}$ is the size-dependent $(\mathrm{SL}, \mathrm{mm})$ stomach threshold value (STV), which defined the hunger level. STV ranges from 0.7 for larval cod of $6 \mathrm{~mm}$ length to 0.3 for larval cod of $18 \mathrm{~mm}$ length (Kristiansen 2007). The shape of the STV function was found by doing an exhaustive search for the optimal STV value for each $0.5 \mathrm{~mm}$ size increment, which was fitted to a function. The search for optimality involved testing all values of STV in the range from 0 to 1 at 0.1 intervals and all sizes of larvae from 6 to $18 \mathrm{~mm}$ at $0.5 \mathrm{~mm}$ intervals (Kristiansen 2007).

Prey selectivity index. Chesson's (1978) prey preference index $\alpha_{i}$ was applied to quantify prey selectivity. The index is a ratio between selected (captured and ingested) prey items, $r_{i}$, relative to the frequency of their occurrence in the environment $\left(n_{i}\right)$ and the ratio of the sum of prey items in the stomach and the environment. Neutral selection (Chesson 1978) is defined as $\alpha_{\text {neutral }}=$ $1 / k$, where $k$ is the number of prey types and stages considered. If values are $>\alpha_{\text {neutral}}$, prey are actively selected as they appear more frequently in the diet than their abundance in the environment would suggest. The model evaluated the index of 4 prey taxa and 13 stages (neutral selection, $\alpha_{\text {neutral }}=0.0192$ ) based on the observed prey field and modeled feeding. For the NoC simulations, we removed Centropages spp. as a prey item and evaluated 3 prey taxa at 13 stages, which gave a neutral selection of $\alpha_{\text {neutral }}=0.0256$. We also estimated Chesson's selectivity index assuming that the 4 prey taxa and all 13 stages were homogenously distributed, to explore how important the abundance of specific taxa and stages can be. The function for the selectivity index is:

$$
\alpha_{i}=\frac{\frac{r_{i}}{n_{i}}}{\sum_{j=1}^{n} \frac{r_{j}}{n_{j}}}
$$

\section{RESULTS}

\section{Zooplankton size distribution}

For analytical purposes we also grouped the prey field into 3 size ranges based on prey width $(\mathrm{d} p, \mathrm{~mm})$ $(\mathrm{d} p<0.15 \mathrm{~mm}, 0.15 \mathrm{~mm} \leq \mathrm{d} p<0.3 \mathrm{~mm}$, and $\mathrm{d} p \geq 0.3 \mathrm{~mm})$ (Fig. 4), which limited the ability of the larva to swallow the prey. Total number of nauplii in the water column varied with depth and between years (Fig. 4). Maximum abundance of all zooplankton size groups occurred in the upper $40 \mathrm{~m}$, with values between 1.5 and 15 prey $\mathrm{l}^{-1}$ (Fig. 4a,b) for the smallest size group and substantially lower values ( 0 to 2 prey $\mathrm{l}^{-1}$ ) for the 2 largest size groups. Patches of high densities of nauplii (smallest size group) and copepodites (the 2 largest size groups) co-occurred (Fig. 4). Copepodites were distributed throughout the water column, although maxima were found at 10 and $30 \mathrm{~m}$ in May 1993 and at $10 \mathrm{~m}$ in May 1994.

\section{Modeled behavior}

Vertical variation in prey abundance, temperature, and predation rate strongly affected the modeled larval behavior for Gadus morhua and therefore also the modeled growth and feeding. In the present model study, larval state dependence (stomach fullness, size) determined the trade-off between ingestion and mortality, and the subsequent vertical behavior. This tradeoff caused diel vertical migration (DVM), with larvae moving downward during the day and towards the surface during the night (Fig. 5). In an environment that contained predators, modeled $7 \mathrm{~mm}$ larvae were mostly located in the upper layer of the water column, between the surface and $20 \mathrm{~m}$ depth (Fig. 5a,b). This depth range was a result of the trade-off between seeking shelter, while still being within swimming distance of the surface layer, where the light level was suitable for feeding. The individuals followed the local maximum abundance of nauplii (upper $15 \mathrm{~m}$ ) in May 1993, while, in 1994, the nauplii were more uniformly distributed and the larvae moved to deeper areas in the water column (Fig. 5a,b). When predation risk was modeled to zero ('no predation'), the larvae stayed in the upper 10 to $15 \mathrm{~m}$ of the water column. The swimming and visual abilities increased considerably from 7 to $9 \mathrm{~mm}$, and therefore the increased DVM range (Fig. 5c,d) allowed the larger larvae to avoid predators in the surface layer during daytime. The average modeled depth position over $5 \mathrm{~d}$ (Fig. 5, $48 \mathrm{~h}$ shown) with (in parentheses, without) predation was 17.0 (16.5) m and 20.1 (15.2) $\mathrm{m}$ for 7 and $9 \mathrm{~mm}$ in May 1993, and 18.0 (16.1) $\mathrm{m}$ and 21.1 (15.2) $\mathrm{m}$ for 7 and $9 \mathrm{~mm}$ in May 1994, 


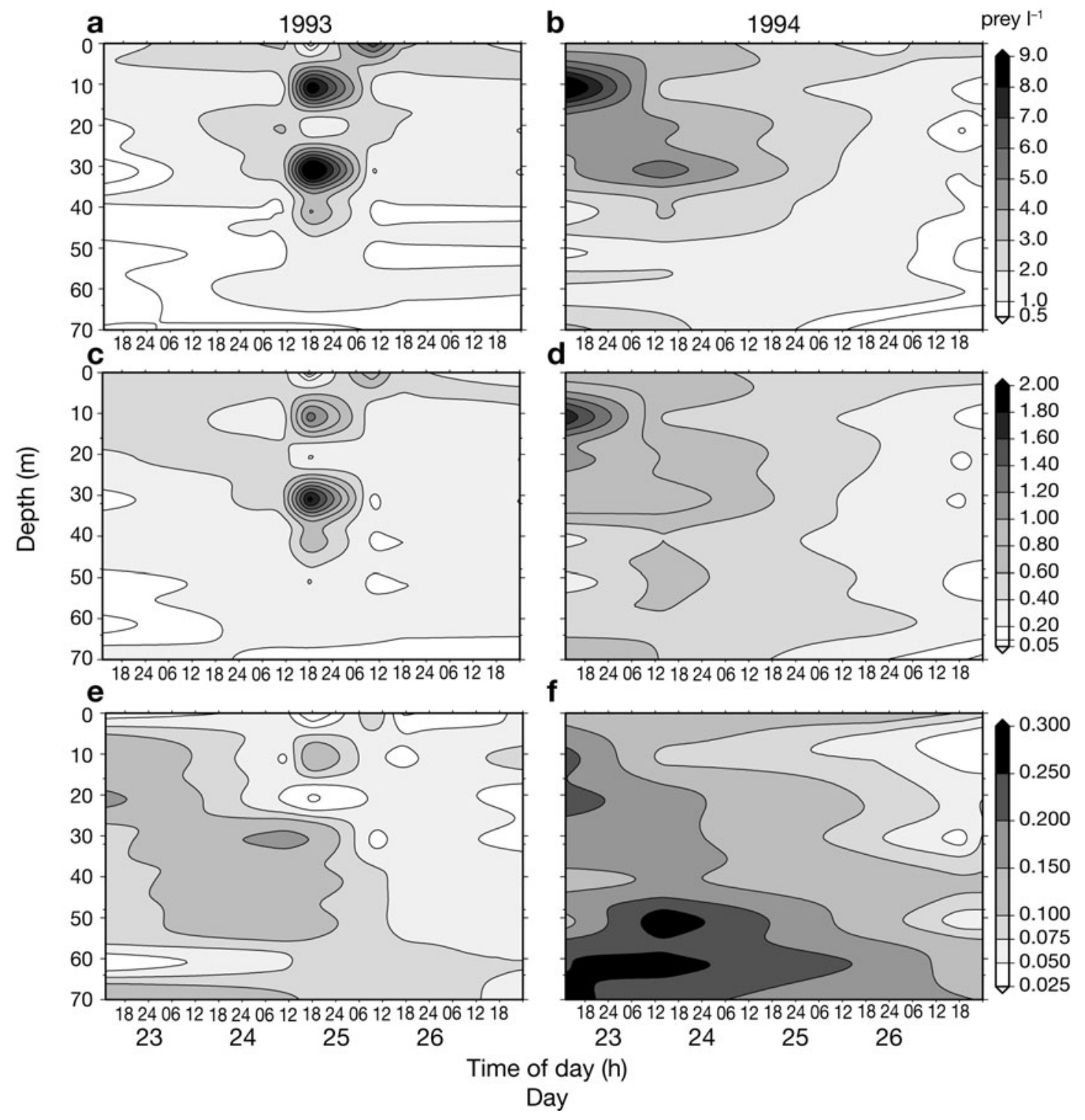

Fig. 4. Distribution of 3 size-classes of prey (prey $\mathrm{l}^{-1}$ ) as observed in May (a,c,e) 1993 and (b,d,f) 1994 (see Fig. 1 for sampling sites). The hour of the day (top) and date (bottom) are shown on the $x$-axis. Prey were divided into sizes based on their width (d $p$ ): (a,b) $\mathrm{d} p<0.15 \mathrm{~mm},(\mathrm{c}, \mathrm{d}) 0.15 \mathrm{~mm} \leq \mathrm{d} p<0.3 \mathrm{~mm}$, and $(\mathrm{e}, \mathrm{f}) \mathrm{d} p>0.3 \mathrm{~mm}$

respectively. Results for modeled behaviors are not shown for $5 \mathrm{~mm}$ larvae, since their modeled behaviors were limited to the surface layer (upper 5 to $15 \mathrm{~m}$ ). For $11 \mathrm{~mm}$ larvae, the behavior was comparable to that for 9 mm larvae.

\section{Observed larval distribution}

The 2 to $5 \mathrm{~mm}$ larvae (Fig. 6) were distributed in the upper $30 \mathrm{~m}$ of the water column. Depth-integrated values of larval abundance differed with time of sampling, which may indicate sampling of different larval cohorts. The 6 to $8 \mathrm{~mm}$ larvae generally remained in the upper $30 \mathrm{~m}$ by day and by night (Fig. 7), with maximum abundance around $20 \mathrm{~m}$. The larger size-class of the 9 to $13 \mathrm{~mm}$ larvae was mainly located in the upper $40 \mathrm{~m}$ (Fig. 8). The field data for this size group also suggest that larvae move throughout the water column and that larval depth distribution can change rapidly.

\section{Modeled and observed larval growth rates}

Average field-derived larval growth rates (RNA:DNA) for all sizes (5 to $9 \mathrm{~mm}$ ) were $10.6 \% \mathrm{~d}^{-1}$ in May 1993 and $9.9 \% \mathrm{~d}^{-1}$ in May 1994 (Table 1), despite a 1.5-fold increase in plankton biomass in 1994. Estimated mod- 
Fig. 5. Gadus morhua. Modeled average depth position of size (a,b) $7 \mathrm{~mm}$ and $(\mathrm{c}, \mathrm{d}) 9 \mathrm{~mm}$ larval cod, in cases where vertical behavior is a trade-off between survival and ingestion rate, and larval state dependence (stomach fullness, size). Modeled behavior is shown for environments with and without risk of predation for May $(\mathrm{a}, \mathrm{c}) 1993$ and (b,d) 1994. Averaged depth estimated from simulating 100 individuals; grey shading indicates standard deviation of depth position with time. Hours of the day are labeled on the $x$-axis, and were restricted to a $48 \mathrm{~h}$ period

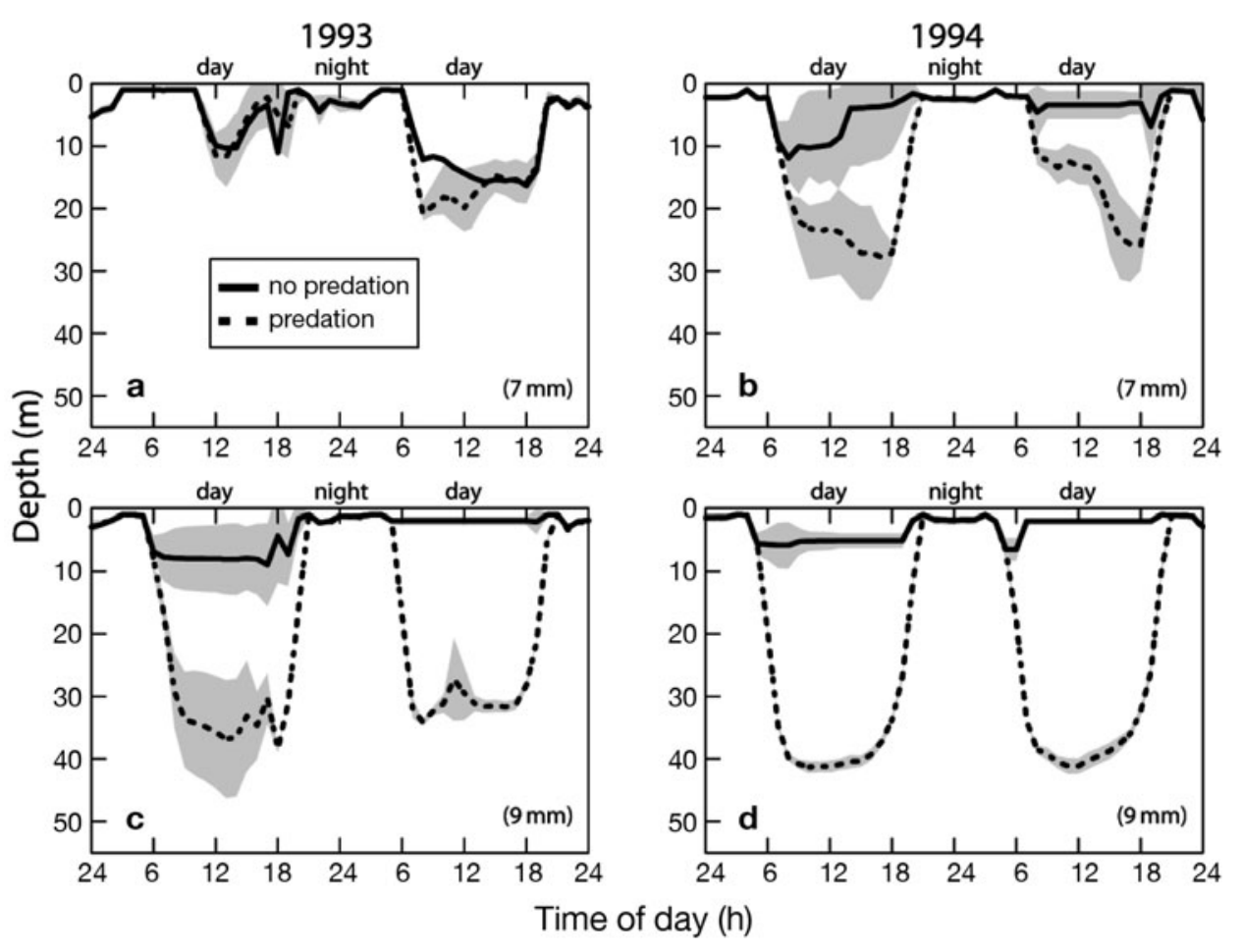

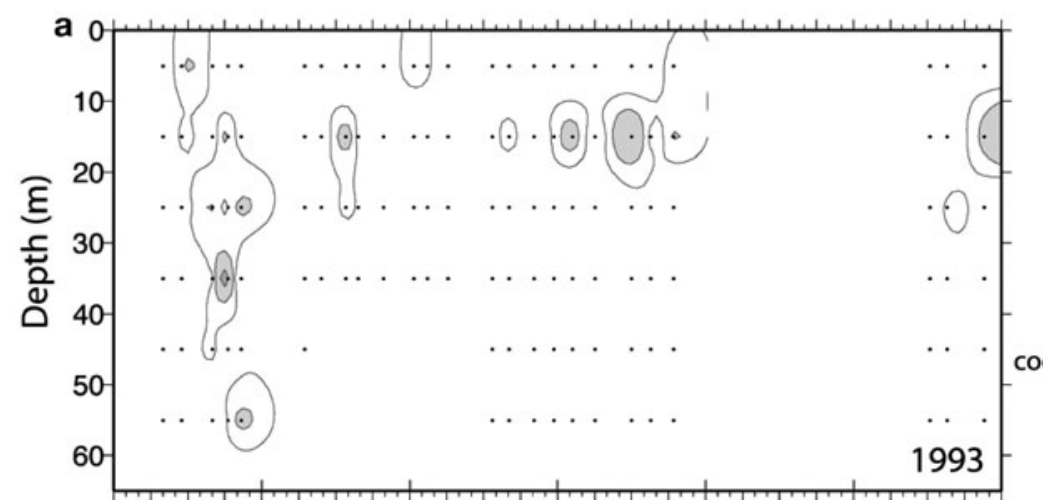

24612182461218246121824612182461218246121824 $\begin{array}{llllll}22 & 23 & 24 & 25 & 26 & 27\end{array}$

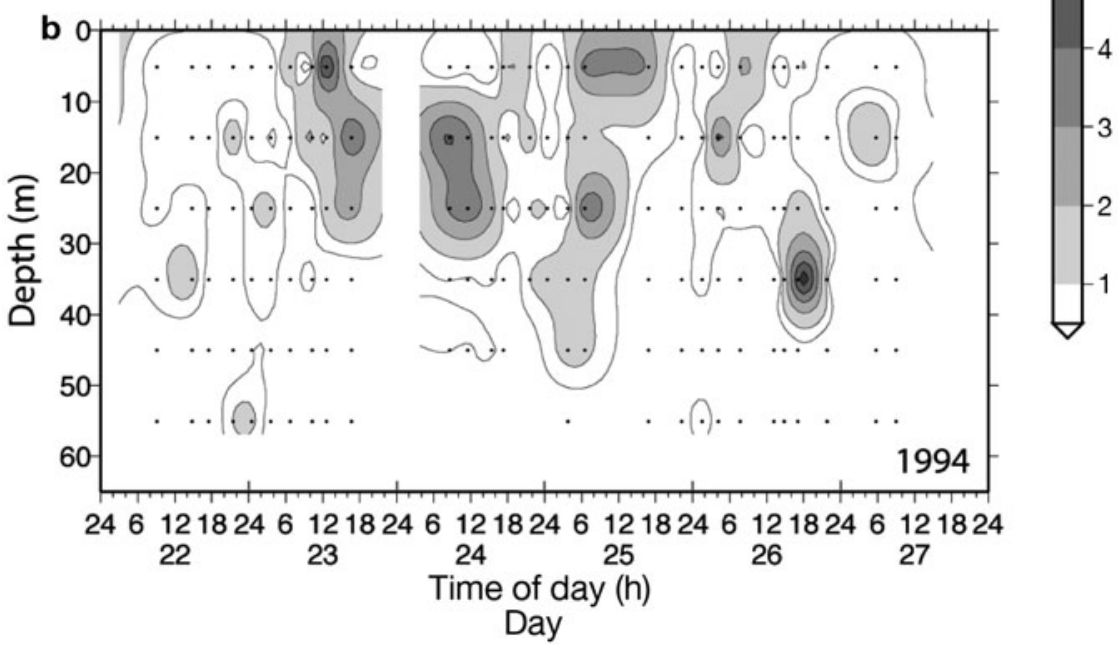

eled growth of $5 \mathrm{~mm}$ larval cod in May 1993 at fixed depths and weighted for observed vertical abundance (WMD) was $3.0 \% \mathrm{~d}^{-1}$. Larvae that exhibited vertical behavior (OPT) in an environment with predation (in parentheses, without predation) experienced growth cod $100 \mathrm{~m}^{-3}$ rates of $5.1(5.1) \% \mathrm{~d}^{-1}$. Field observations for $5 \mathrm{~mm}$ larvae revealed a mean growth $( \pm \mathrm{SD})$ rate of $7.6 \pm 2.4 \% \mathrm{~d}^{-1}$. For 6 1994, modeled growth rates for $5 \mathrm{~mm}$ larvae were $4.6 \% \mathrm{~d}^{-1}$ for WMD and 6.8 $-5 \quad(6.8) \% \mathrm{~d}^{-1}$ for OPT (Table 1). Observed growth rates increased with larval size, with a maximum of $12.9 \pm 1.6 \% \mathrm{~d}^{-1}$ for $9 \mathrm{~mm}$ larvae in $1993\left(10.4 \pm 2.0 \% \mathrm{~d}^{-1}\right.$ in 1994). The simulated growth rates were slightly higher in 1994 than in 1993 due to the increased temperature and abundance of prey. This suggests that the number of potential prey available in

Fig. 6. Gadus morhua. Distribution of larval cod (2 to $5 \mathrm{~mm}$ ) during May (a) 1993 and (b) 1994. The $x$-axis indicates hour of the day (local time) from 22 to 27 May each year. Black circles denote 1 sampling station. Areas with few or no sampling locations are masked out in white 
Fig. 7. Gadus morhua. Distribution of larval cod (6 to $8 \mathrm{~mm}$ ) during May (a) 1993 and (b) 1994. The $x$-axis indicates hour of the day (local time) from 22 to 27 May each year. Black circles denote 1 sampling station. Areas with few or no sampling locations are masked out in white

1994 provided enough energy for the larger larvae to sustain the elevated metabolic cost caused by increased temperature.

TDG rates were higher for all sizes of larvae compared to the modeled growth rates that accounted for prey density (OPT, WMD, and NoC). Consequently, larval fish that were able to migrate vertically to optimize the vertical distribution of prey in the water column were food limited (Table 1). For food-limited simulations, $9 \mathrm{~mm}$ larvae reached a maximum growth rate of $14.6 \%$ $\mathrm{d}^{-1}$ in 1994. The lowest modeled and observed growth rates were found for $5 \mathrm{~mm}$ larvae.

When predators were removed from the environment and the larvae were able to

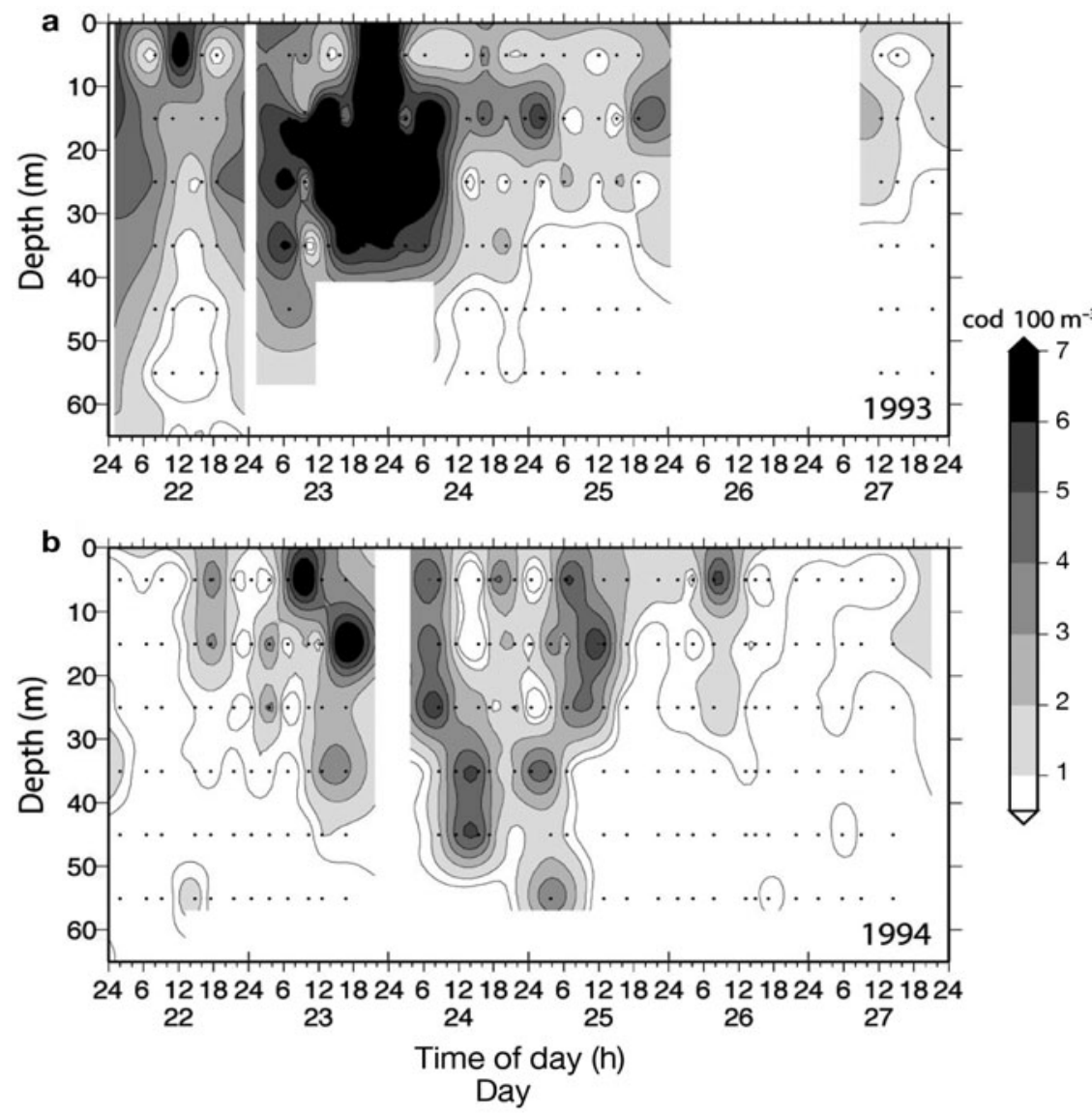

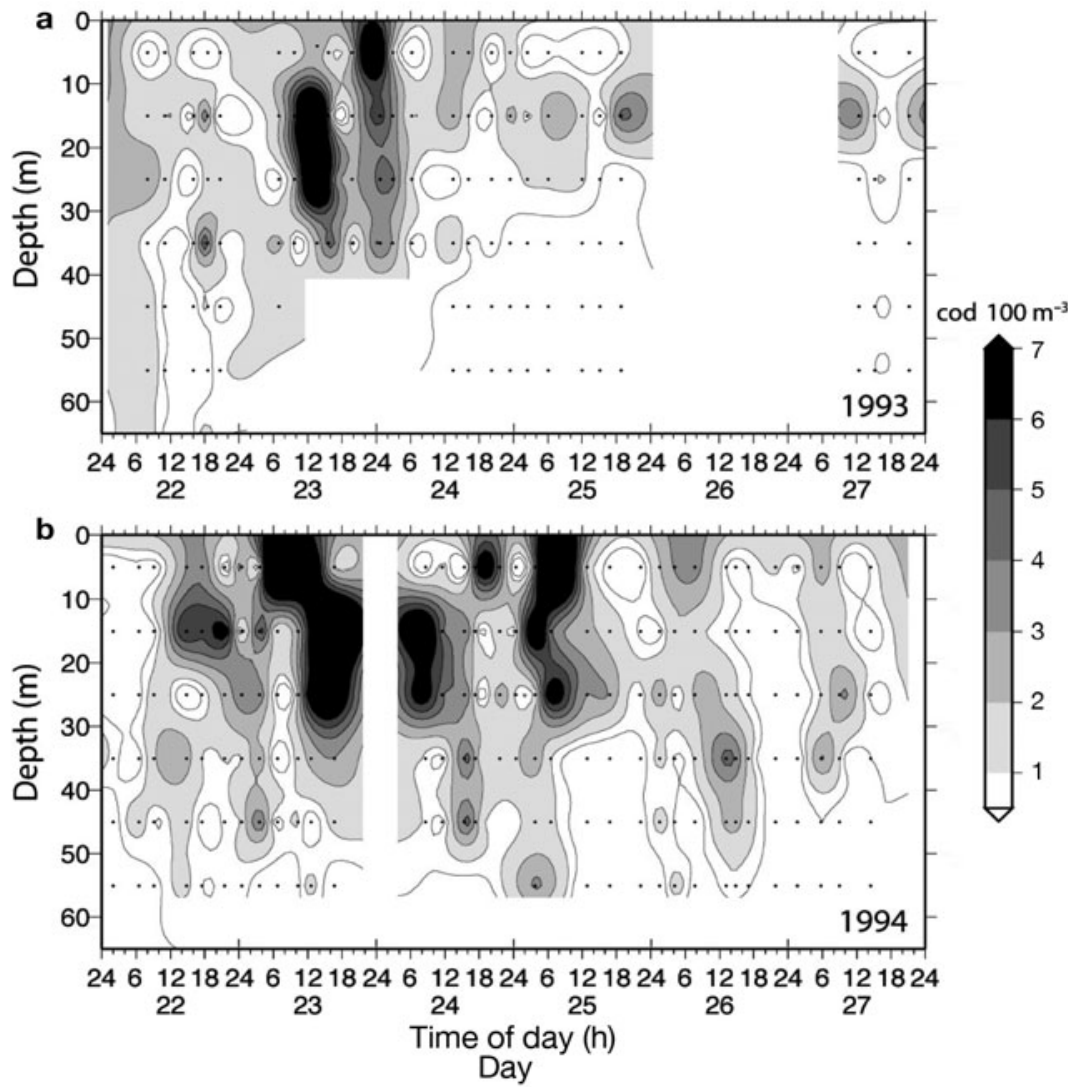

optimize their growth rates (OPT), the growth rates were higher compared to those in environments with predation. With no risk of being eaten, the larvae would stay in the surface layer and feed continuously during light hours, without having to seek out deeper areas to find shelter (Fig. 5).

\section{Modeled prey selection at constant prey densities}

Comparisons between observed (gut analysis) and modeled capture success agreed well, except for small differences for the largest prey items available to $5 \mathrm{~mm}$ (Fig. 9a) and $8 \mathrm{~mm}$ larval cod (Fig. 9b). The species-specific length and width (Fig. 10a) of the prey represent

Fig. 8. Gadus morhua. Distribution of larval cod (9 to $13 \mathrm{~mm}$ ) during May (a) 1993 and (b) 1994. The $x$-axis indicates hour of the day (local time) from 22 to 27 May each year. Black circles denote 1 sampling station. Areas with few or no sampling locations are masked out in white 
Table 1. Gadus morhua. Mean observed (Obs.) growth rates $\left(\% \mathrm{~d}^{-1}\right)$ from RNA:DNA measurements (Lough et al. 2005) for 4 sizes of larval cod compared to modeled growth rates for May 1993 and 1994. Simulated growth rates for larval cod were averaged throughout the water column and weighted by observed (Lough et al. 2005) abundance at depth (weighted mean depth, WMD). Also shown are averaged $( \pm$ SD) growth rates for 100 individuals that exhibit vertical behavior that optimized (OPT) ingestion rate and minimized mortality risk. Simulation results with and without predation shown. Temperature-dependent growth rate (TDG) estimated assuming excessive amounts of food. TDG restricted larval growth to their physiological maximum (Folkvord 2005). Simulations in which Centropages spp. were excluded as potential prey denoted NoC (no Centropages). Vertical behavior of TDG and NoC was identical to OPT behavior. na: data not available

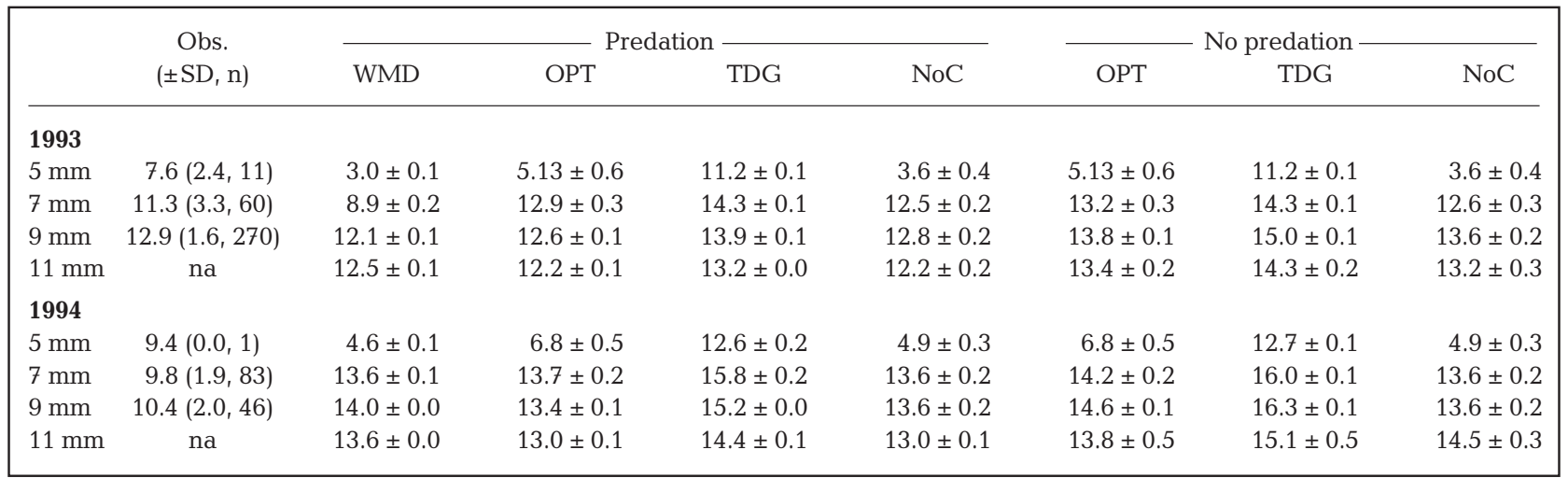

characteristics that determine visibility to larval cod, while prey swimming speed and jump angle affected larval capture success. Given equal densities of the 4 prey taxa, Oithona spp. were the preferred simulated prey for 5 and $9 \mathrm{~mm}$ larvae (Fig. 10b,c). This is likely a result of the slow swimming speeds among Oithona spp. and their relatively large width to length ratio, which increases their visibility (image area) and thus their encounter rate with larval cod (Fig. 10a). Simulated preferred ratio between prey and predator length was 0.06 for $5 \mathrm{~mm}$ larvae and 0.05 for $9 \mathrm{~mm}$ larvae.

\section{Modeled and observed prey selection with varying prey densities}

When the observed prey densities were used as input to the IBM, Pseudocalanus spp. and Centropages spp. were the most important modeled prey items regardless of larval size (Table 2). The 2 species accounted for about 60 to $80 \%$ of the prey items in the modeled gut for both 1993 and 1994, regardless of whether predation pressure was turned on or off. Pseudocalanus spp. nauplii were twice as abundant as Centropages spp. nauplii in 1993 and 3-fold more
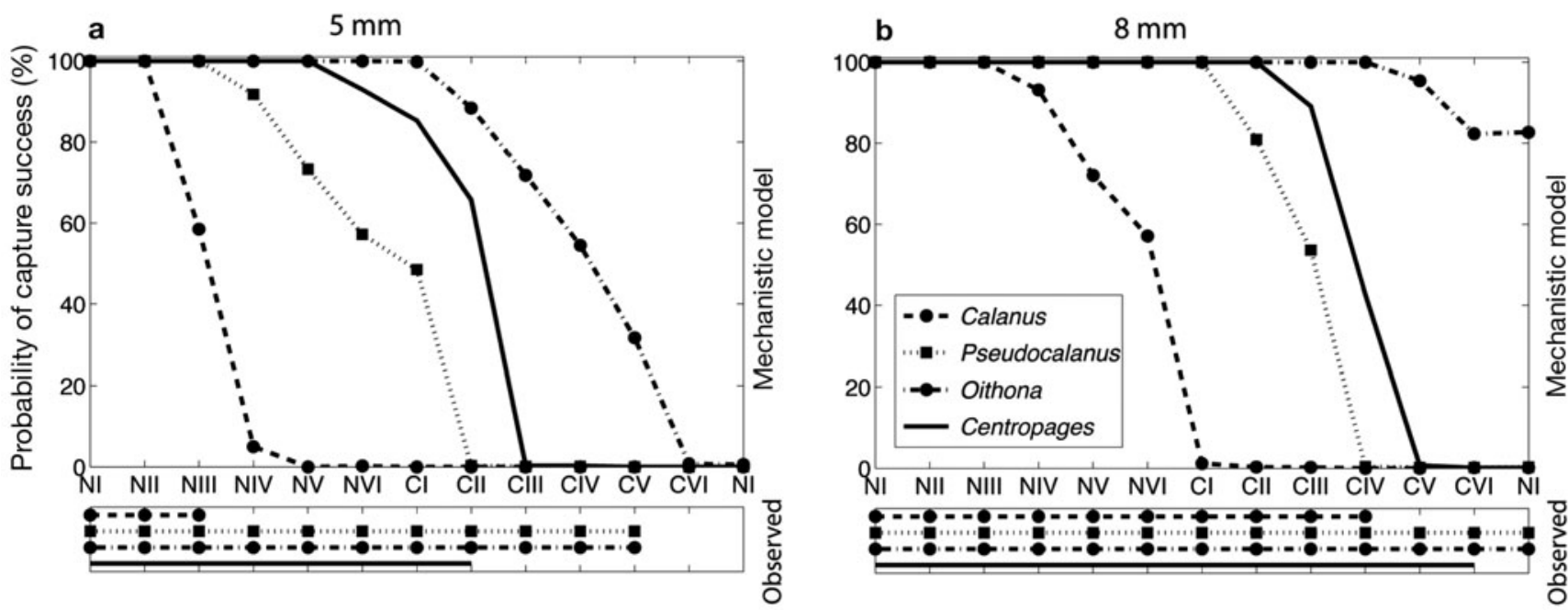

Fig. 9. Gadus morhua. Modeled probability (\%) of capture success for (a) $5 \mathrm{~mm}$ and (b) $8 \mathrm{~mm}$ larval cod. Modeled values were averaged over 1000 capture attempts per prey taxa (Calanus finmarchicus, Pseudocalanus spp., Oithona spp. and Centropages spp.) and stage. Shown below the graph is the observed presence/absence of prey in the stomach/gut observations of 2 to $5 \mathrm{~mm}$ and 6 to $8 \mathrm{~mm}$ larval cod (Lough et al. 2005) 


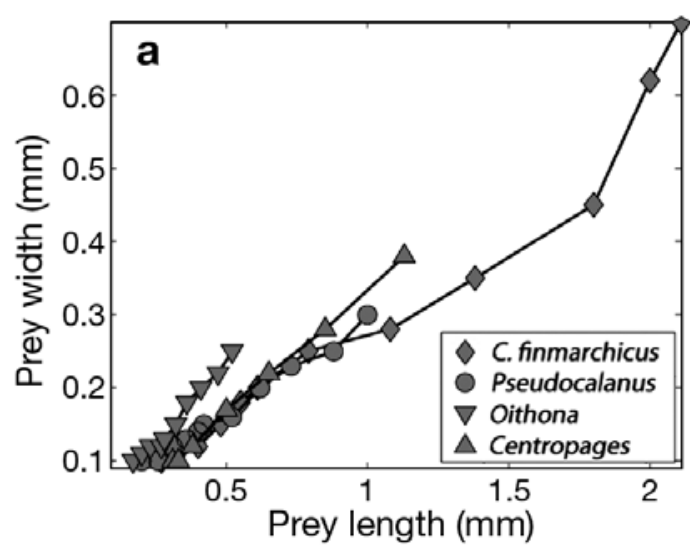

Fig. 10. Calanus finmarchicus, Pseudocalanus spp., Oithona spp. and Centropages spp. (Davis 1987). (a) Length and width of 13 developmental stages for 4 taxa and 13 stages. Estimated average Chesson's prey preference index when we assume constant and uniform prey densities are shown for (b) $5 \mathrm{~mm}$ and (c) $9 \mathrm{~mm}$ larval cod Gadus morhua. Horizontal grey line $(\mathrm{b}, \mathrm{c})$ denotes neutral selection

abundant in 1994. The high frequency of Pseudocalanus spp. in the gut observations was explained by the model as an effect of high differential encounter rate between larval cod and Pseudocalanus spp., combined with the larva's ability to capture Pseudocalanus spp. In agreement with modeled prey selection, stomach samples showed high numbers of Pseudocalanus spp. for all larval sizes, but only a few (0 to $19 \%$ ) Centropages spp. (Table 3). Oithona spp. accounted for 14 to $37 \%$ of the prey items in the modeled diet for all larval sizes (Table 2), comparable with stomach samples (Table 3). Low preference for Calanus finmarchicus was predicted from both modeled ( 0 to $7 \%$ ) and observed ( 0 to $1 \%$, valid for 6 to 8 $\mathrm{mm}$ ) stomach contents (Tables $2 \&$ 3). C. finmarchicus was by far the largest copepod prey available, but its width, length, and swimming speed constrained the modeled capture efficiency (Fig. 9). Table 2 summarizes the values of Chesson's prey preference index for all stages, and Fig. 11 illustrates the preference for both prey stages and species. Modeled 5 mm larvae forage mainly on nau-

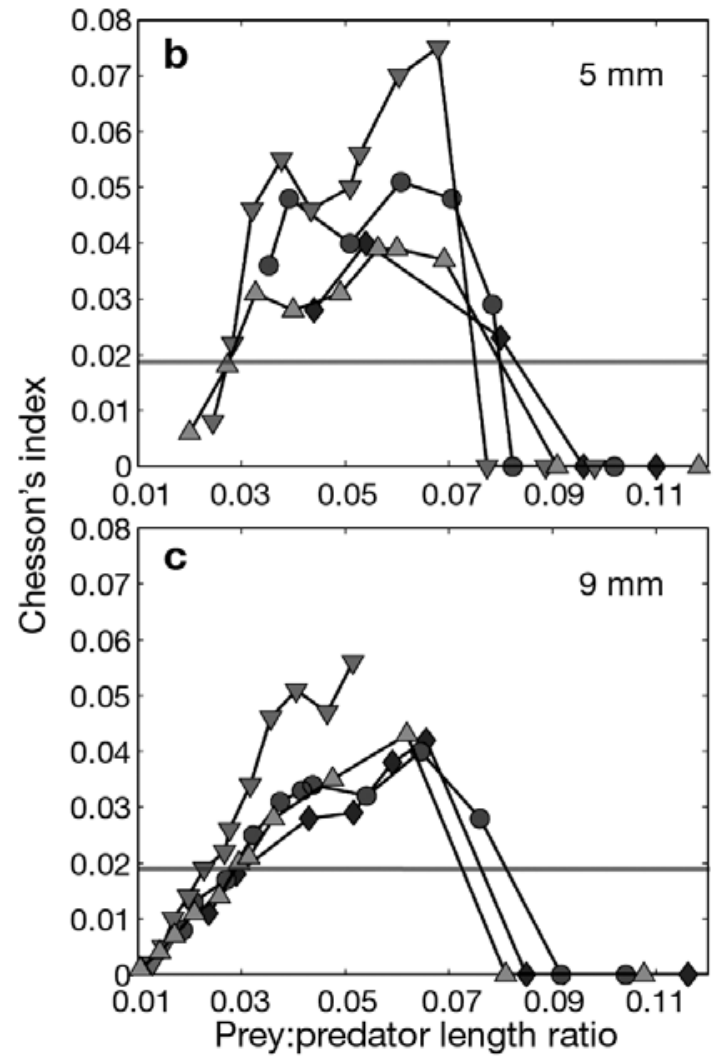

pliar stages; however, for Pseudocalanus spp., Centropages spp., and Oithona spp., the smallest copepodite stages can also be preyed upon (Fig. 11). C. finmarchicus was nearly absent as prey for $5 \mathrm{~mm}$ larvae, with the exception of the smallest naupliar stages (Figs. 9a,b, 11a,b, \& 12a,b).

Simulated $9 \mathrm{~mm}$ larval cod foraged on nearly all available copepod prey items (Fig. 11c,d), with the exception of the largest Calanus finmarchicus. Modeled gut contents indicated high selection for Pseudo-

Table 2. Gadus morhua. Simulated Chessons' alpha index for the environmental conditions in May 1993 and 1994 for 4 sizes of larval cod with and without predation. Chesson index values were calculated for individuals that exhibited vertical behavior following the optimized trajectory (OPT) rule. All prey stages within species were summed, and the level of neutral selection was therefore $\alpha_{\text {neutral }}=0.25$

\begin{tabular}{|c|c|c|c|c|c|c|c|c|}
\hline \multirow[t]{2}{*}{ Prey } & \multicolumn{4}{|c|}{$\longrightarrow$ Predation -} & \multicolumn{3}{|c|}{-No predation } & \multirow{2}{*}{$\overline{11 \mathrm{~mm}}$} \\
\hline & $5 \mathrm{~mm}$ & $7 \mathrm{~mm}$ & $9 \mathrm{~mm}$ & $11 \mathrm{~mm}$ & $5 \mathrm{~mm}$ & $7 \mathrm{~mm}$ & $9 \mathrm{~mm}$ & \\
\hline \multicolumn{9}{|l|}{ May 1993} \\
\hline Calanus finmarchicus & 0.02 & 0.02 & 0.07 & 0.03 & 0.02 & 0.04 & 0.12 & 0.02 \\
\hline Pseudocalanus spp. & 0.31 & 0.38 & 0.46 & 0.52 & 0.31 & 0.40 & 0.40 & 0.44 \\
\hline Oithona spp. & 0.32 & 0.28 & 0.14 & 0.15 & 0.32 & 0.25 & 0.31 & 0.26 \\
\hline Centropages spp. & 0.37 & 0.32 & 0.39 & 0.31 & 0.37 & 0.33 & 0.28 & 0.28 \\
\hline \multicolumn{9}{|l|}{ May 1994} \\
\hline Calanus finmarchicus & 0.00 & 0.03 & 0.03 & 0.07 & 0.00 & 0.02 & 0.04 & 0.04 \\
\hline Pseudocalanus spp. & 0.30 & 0.39 & 0.42 & 0.50 & 0.30 & 0.37 & 0.37 & 0.43 \\
\hline Oithona spp. & 0.37 & 0.24 & 0.28 & 0.14 & 0.37 & 0.37 & 0.35 & 0.27 \\
\hline Centropages spp. & 0.33 & 0.33 & 0.27 & 0.31 & 0.33 & 0.29 & 0.24 & 0.26 \\
\hline
\end{tabular}


Table 3. Gadus morhua. Chesson's alpha index based on observations in May 1993 (59 observations) and 1994 (41 observations), including the 4 most important prey taxa of larval cod on Georges Bank. Neutral selection was $\alpha_{\text {neutral }}=0.25$

\begin{tabular}{|lcc|}
\hline Prey & May 1993 & May 1994 \\
\hline Calanus finmarchicus & 0.00 & 0.00 \\
Pseudocalanus spp. & 0.82 & 0.46 \\
Oithona spp. & 0.18 & 0.35 \\
Centropages spp. & 0.00 & 0.19 \\
\hline
\end{tabular}

calanus spp. and Centropages spp., with a preference for copepodite stages CI to CIV (Fig. 11c,d). There was good agreement between observed and modeled stomach content values of 6 to $8 \mathrm{~mm}$ larvae, with the exception of Centropages spp., which was nearly absent from the observed diet. The larvae likely compensated for the absence of Centropages spp. by foraging on Pseudocalanus spp., which accounted for 46 to $82 \%$ of the observed stomach contents (Table 3 ).

Observed gut contents of 6 to $8 \mathrm{~mm}$ larval cod showed low numbers of Centropages spp. When we assumed that Centropages spp. was negatively selected (for unknown reasons) and removed Centropages spp. as a potential prey in the model, the modeled numbers of Pseudocalanus spp. and Oithona spp. in the stomach increased (Fig. 12, Table 4). The larval selection on Calanus finmarchicus did not increase, as abundance was generally low and C. finmarchicus were difficult for cod larvae to capture. When we removed Centropages spp. as a prey item, small larvae (5 to $7 \mathrm{~mm}$ ) increased the numbers of Oithona spp. on which they fed, while larger larvae (9 to $11 \mathrm{~mm}$ ) mainly fed on Pseudocalanus spp. (Fig. 12, Table 4).

\section{DISCUSSION}

Year-class strength is often regarded as largely determined by the number of larval fish that survive the first 6 mo after hatching (Hjort 1914, Sundby et al. 1989, Houde 1997). During this period, the combination of the right prey and the larval ability to capture prey is a requirement for larval growth and survival (Cushing 1996, Beaugrand et al. 2003). On Georges Bank, Pseudocalanus spp. is the main prey item for larval cod Gadus morhua (Kane 1984, Campana et al. 1989, Lough \& Mountain 1996, Buckley \& Durbin 2006, Kane 2007), i.e. this prey item is that most frequently found in gut samples of newly hatched to metamor-
Fig. 11. Gadus morhua. Modeled average Chessons' prey preference index for $(a, b) 5$ and (c,d) $9 \mathrm{~mm}$ larval cod (100 ind.) in May $(\mathrm{a}, \mathrm{c})$ 1993 and (b,d) 1994. Horizontal grey line denotes level of neutral selection $\left(\alpha_{\text {neutral }}=0.0192\right)$. Values above this line indicate a preference for these prey items, as they are more frequently selected than they appear in the environment

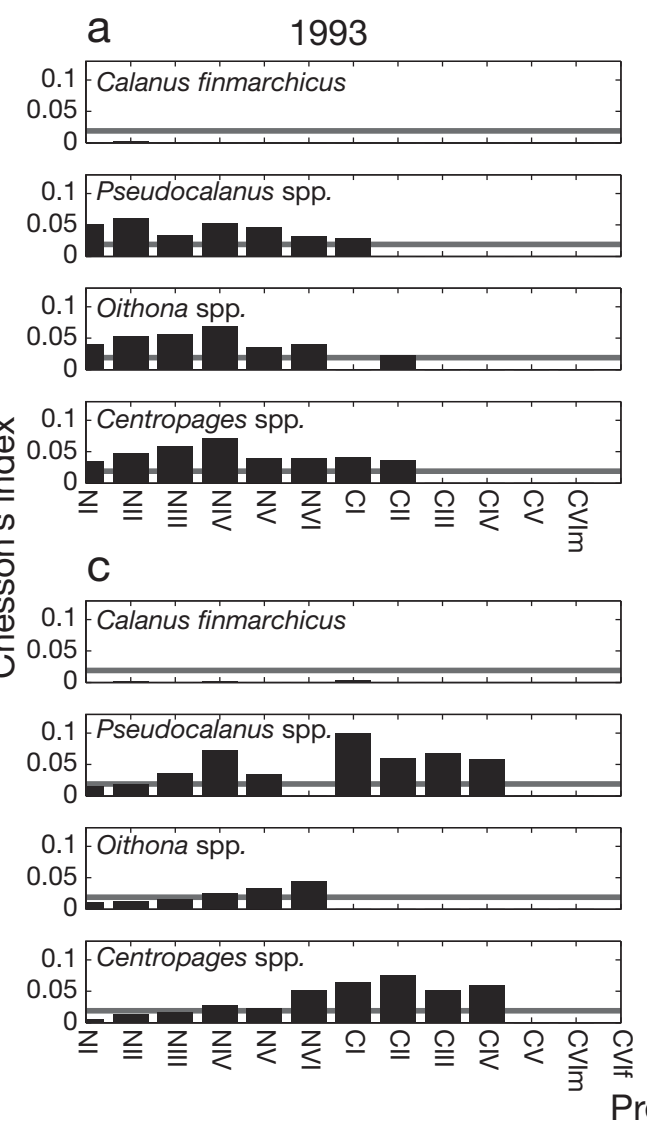

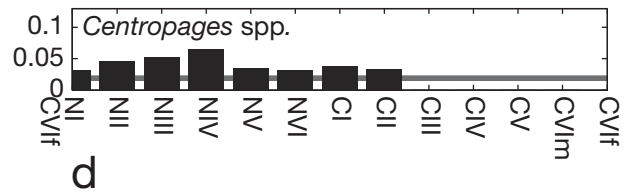
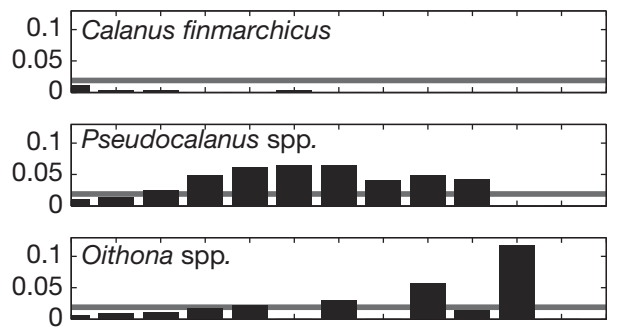


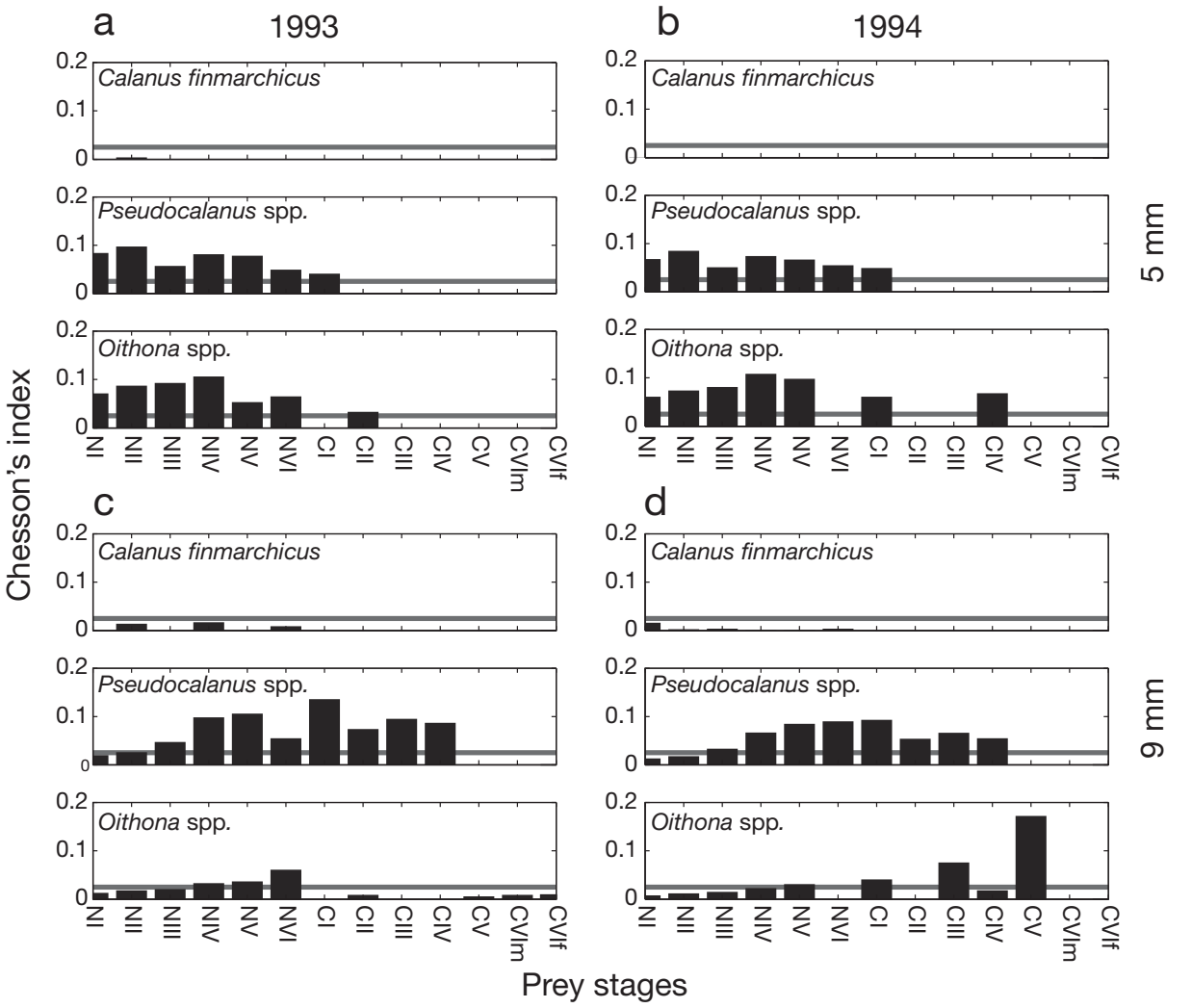

Fig. 12. Gadus morhua. Modeled average Chessons' prey preference index for (a) 5 and (b) $9 \mathrm{~mm}$ larval cod (100 ind.) in May $(\mathrm{a}, \mathrm{c}) 1993$ and $(\mathrm{b}, \mathrm{d})$ 1994, assuming Centropages spp. are unavailable as prey items. Horizontal bold grey line denotes level of neutral selection $\left(\alpha_{\text {neutral }}\right.$ $=0.025)$. Values above this line indicate a preference for these prey items, as they are more frequently selected than they appear in the environment phosed cod. The results presented suggest that the observed high frequency of Pseudocalanus spp. in the larval cod gut can be explained by a high differential encounter rate between larval cod and the prey. The differential encounter rate was caused by the visibility of Pseudocalanus spp. in the water column, combined with the ability of larval cod to capture this prey taxon, as well as the relatively high abundance of this prey item and an overlapping vertical distribution of Pseudocalanus spp. and larval cod (Kane 2007). What is usually referred to as a prey preference for Pseudocalanus spp. is actually a mechanistic effect of the biotic and

Table 4. Gadus morhua. Simulated Chessons' alpha index for the environmental conditions in May 1993 and 1994 for 4 sizes of larval cod in environments with and without predation, assuming no Centropages spp. in the water column. All prey stages within species were summed and the level of neutral selection was $\alpha_{\text {neutral }}=0.33$

\begin{tabular}{|c|c|c|c|c|c|c|c|c|}
\hline \multirow[t]{2}{*}{ Prey } & \multicolumn{4}{|c|}{$\longrightarrow$ Predation -} & \multicolumn{4}{|c|}{-No predation } \\
\hline & $5 \mathrm{~mm}$ & $7 \mathrm{~mm}$ & $9 \mathrm{~mm}$ & $11 \mathrm{~mm}$ & $5 \mathrm{~mm}$ & $7 \mathrm{~mm}$ & $9 \mathrm{~mm}$ & $11 \mathrm{~mm}$ \\
\hline \multicolumn{9}{|l|}{ May 1993} \\
\hline Calanus finmarchicus & 0.04 & 0.01 & 0.04 & 0.05 & 0.04 & 0.01 & 0.03 & 0.03 \\
\hline Pseudocalanus spp. & 0.49 & 0.50 & 0.75 & 0.74 & 0.49 & 0.50 & 0.60 & 0.60 \\
\hline Oithona spp. & 0.50 & 0.49 & 0.22 & 0.21 & 0.50 & 0.49 & 0.38 & 0.37 \\
\hline \multicolumn{9}{|l|}{ May 1994} \\
\hline Calanus finmarchicus & 0.00 & 0.02 & 0.03 & 0.10 & 0.00 & 0.02 & 0.05 & 0.05 \\
\hline Pseudocalanus spp. & 0.45 & 0.57 & 0.58 & 0.70 & 0.45 & 0.55 & 0.48 & 0.51 \\
\hline Oithona spp. & 0.55 & 0.41 & 0.40 & 0.20 & 0.55 & 0.44 & 0.47 & 0.44 \\
\hline
\end{tabular}

abiotic components of the water column and not an active selection of larval cod, which is consistent with studies of the feeding ecology of bay anchovy Anchoa mitchilli (Luo et al. 1996).

Clearly, Pseudocalanus spp. are predominant prey items in the diet of larval cod because of their abundance, visibility, and the larval ability to capture these prey items. However, Centropages spp. and Pseudocalanus spp. copepodites are comparable in length and width (and thereby in image area), and, since escape behavior of the prey was simulated as a size-dependent function, Centropages spp. were simulated to be prey items for larval cod. If a more complex species-specific prey behavior had been included in this model, it is probable that Centropages spp. copepodites would not have been found to be an important component in the diet of larval cod. Centropages spp. are omnivorous predators and have behaviors that differ from the predominantly herbivorous Pseudocalanus spp. (Davis 1987), e.g. a faster reaction pattern and superior swimming abilities (Tiselius \& Jonsson 1990, Titelman 2001) that make these prey difficult to pur- 
sue and capture. If the behavior of Centropages spp. is mainly ambush or tactile, encounters between larval cod and Centropages spp. may also be lower compared to the suspension-feeding Pseudocalanus spp. In the present study, when Centropages spp. was removed as a potential prey item, the modeled (Table 4) and observed (Table 3) prey selection agreed well, and the modeled growth rates (Table 1) were mainly within a standard deviation of the observed growth rates. Still, proper treatment of including species-specific behavior is not trivial and will be the focus of continued research. Our analyses were limited to 5-15 mm larvae/juveniles, but older stages of cod may show more active selection. Recent work by Rowlands et al. (2008) suggests that cod indeed have a selectivity preference for prey when they reach the stages succeeding metamorphosis.

Light and visual perception are known to be key components of understanding foraging ecology (Blaxter 1986, Gilbert et al. 1992, Aksnes \& Giske 1993, Aksnes \& Utne 1997), but models rarely contain such a level of complexity and detail. One reason may be that model reliability depends on the underlying assumptions of the model and the model's ability to reproduce observable patterns. Laboratory experiments, in which scientists have identified and explored the properties of a single process, or a multitude of processes, provide information on the relevant parts of an IBM. As the number of processes included in the model grows, the complexity and the room for error increase as well. Elements of a model should therefore be limited to the ones thoroughly studied and well documented. The results we have shown here suggest that high complexity may be required to understand how the visual aspect of feeding may be a controlling factor for prey selection.

Visual hunters such as larval cod depend on light to feed. In aquatic environments, light changes exponentially with depth, and the total surface irradiance depends on the day of the year and the latitude. This means that the vertical position of the larva will play an important role in total encounter rate between prey and predator. Here, behavior was modeled as a tradeoff between local predation pressure and ingestion rate, and modeled growth and gut content were close to observed values. When the predation rates were turned off, most of the simulated larvae were located in the surface $10 \mathrm{~m}$ during the day (Fig. 5), which resulted in increased growth. However, field observations indicated that cod larvae were collected throughout the upper $30 \mathrm{~m}$ of the water column, with a changing diel vertical distribution pattern (Figs. 6 to 8). Since the invertebrate predation rate was constant, the surviving simulated larvae in the surface water could be attributed to the variable vertebrate predation rate. As this surface pattern was not observed in the field larvae, it probably indicates the more episodic nature of verte- brate predation (Garrison et al. 2000), which is more difficult to model for site-specific comparisons. Behavioral dynamics are critical for accurately modeling the long- and short-term effects of vertical position (Fiksen et al. 2007, Vikebø et al. 2007). The local prey and predator environment influences the short-term effects through the larval potential to find food and avoid being eaten. The long-term effects of vertical behavior are caused by vertical gradients in the ocean currents. Larval fish at different depths will be exposed to different ocean currents, and therefore experience different pathways during their pelagic stages. Consequently, this will affect the success of larvae in reaching favorable nursery grounds (Fiksen et al. 2007), which can have consequences at the population level.

Light, food, and temperature operate simultaneously and provide the habitat for first-feeding larval cod. The combination of these properties will therefore constrain the feeding, growth and survival of larval cod, as has been suggested in several papers (e.g. Buckley et al. 2004, 2006, Buckley \& Durbin 2006). Our model results were consistent with gut samples from 1993 and 1994, with the exception of Centropages spp. copepodites. In times when food is scarce, it is likely that other species may provide energy for larvae in addition to the 4 main prey taxa we have included in the present study. Such events may result in reduced quality of the food, e.g. reduced average size of prey, which may negatively affect cod growth, survival, and recruitment success (Beaugrand 2003). From laboratory studies we also know that larval growth can be food limited at higher temperatures. Field growth rates estimated for cod on Georges Bank suggest foodlimited growth at temperatures exceeding $7^{\circ} \mathrm{C}$ for May 1994 (Buckley et al. 2004).

The feeding component of the IBM presented here explains important details of the feeding behavior of larval cod, which were verified with field data. In particular, we have shown that the high frequency of Pseudocalanus spp. in larval cod guts can be explained by light, optical properties of the environment, the prey and the fish, and the prey distribution and abundance. For future IBMs it is important to incorporate prey behavior in addition to prey visibility and escape speed, because all 3 parameters are likely to affect predation dynamics (Utne-Palm 2000). Behavioral differences between prey species (Buskey et al. 2002, Titelman \& Kiørboe 2003) may also elucidate prey selection patterns of larval fish. However, incorporating prey behavior is complex and requires a thorough functional representation and understanding of each species' movement and behavior. Nonetheless, using our current model we can better understand growth and survival of cod under varying environmental conditions. 
Acknowledgements. The authors thank E. R. Selig and 3 anonymous reviewers for very helpful comments and suggestions on the manuscript. We acknowledge support from the Norwegian Research Council through the ECOBE program, and from NSF/NOAA through the US-GLOBEC Phase 4B program. This is GLOBEC contribution number 617.

\section{LITERATURE CITED}

Aksnes DL, Giske J (1993) A theoretical-model of aquatic visual feeding. Ecol Model 67:233-250

Aksnes DL, Utne ACW (1997) A revised model of visual range in fish. Sarsia 82:137-147

Beaugrand G (2003) Long-term changes in copepod abundance and diversity in the north-east Atlantic in relation to fluctuations in the hydroclimatic environment. Fish Oceanogr 12:270-283

Beaugrand G, Brander KM, Lindley JA, Souissi S, Reid PC (2003) Plankton effect on cod recruitment in the North Sea. Nature 426:661-664

Blaxter JHS (1986) Development of sense organs and behavior of teleost larvae with special reference to feeding and predator avoidance. Trans Am Fish Soc 115(1):98-114

Buckley LJ, Dillmann DW (1982) Nitrogen utilization by larval summer flounder, Paralichthys dentatus (Linnaeus). J Exp Mar Biol Ecol 59:243-256

Buckley LJ, Durbin EG (2006) Seasonal and inter-annual trends in the zooplankton prey and growth rate of Atlantic cod (Gadus morhua) and haddock (Melanogrammus aeglefinus) larvae on Georges Bank. Deep-Sea Res II 53: 2758-2770

Buckley LJ, Caldarone EM, Lough RG (2004) Optimum temperature and food-limited growth of larval Atlantic cod (Gadus morhua) and haddock (Melanogrammus aeglefinus) on Georges Bank. Fish Oceanogr 13:134-140

Buckley LJ, Caldarone EM, Lough RG, St. Onge-Burns JM (2006) Ontogenetic and seasonal trends in recent growth rates of Atlantic cod and haddock larvae on Georges Bank: effects of photoperiod and temperature. Mar Ecol Prog Ser 325:205-226

Buskey EJ, Lenz PH, Hartline DK (2002) Escape behavior of planktonic copepods in response to hydrodynamic disturbances: high speed video analysis. Mar Ecol Prog Ser 235:135-146

Campana SE, Frank KT, Hurley CF, Koeller PA, Page FH, Smith PC (1989) Survival and abundance of young Atlantic cod (Gadus morhua) and haddock (Melanogrammus aeglefinus) as indicators of year-class strength. Can J Fish Aquat Sci 46:171-182

Caparroy P, Thygesen UH, Visser AW (2000) Modelling the attack success of planktonic predators: patterns and mechanisms of prey size selectivity. J Plankton Res 22:1871-1900

Chambers RC, Trippel EA (eds) (1997) Early life history and recruitment in fish populations. Chapman \& Hall, London

Chesson J (1978) Measuring preference in selective predation. Ecology 59:211-215

Cushing DH (1996) Towards a science of recruitment in fish populations. Ecology Institute, Oldendorf/Luhe

Davis CS (1987) Zooplankton life cycles. In: Backus RH, Bourne DW (eds) Georges Bank. MIT Press, London, p 1-593

Eggers DM (1977) Nature of prey selection by planktivorous fish. Ecology 58:46-59

Fiksen Ø, MacKenzie BR (2002) Process-based models of feeding and prey selection in larval fish. Mar Ecol Prog Ser 243:151-164
Fiksen $\varnothing$, Aksnes DL, Flyum MH, Giske J (2002) The influence of turbidity on growth and survival of fish larvae: a numerical analysis. Hydrobiologia 484:49-59

Fiksen Ø, Jørgensen C, Kristiansen T, Vikebø F, Huse G (2007) Linking behavioural ecology and oceanography: larval behaviour determines growth, mortality and dispersal. Mar Ecol Prog Ser 347:195-205

Finn N, Rønnestad I, van der Meeren T, Fyhn HJ (2002) Fuel and metabolic scaling during the early life stages of Atlantic cod Gadus morhua. Mar Ecol Prog Ser 243: $217-234$

Folkvord A (2005) Comparison of size-at-age of larval Atlantic cod (Gadus morhua) from different populations based on size- and temperature-dependent growth models. Can J Fish Aquat Sci 62:1037-1052

Garrison LP, Michaels W, Link JS, Fogarty MJ (2000) Predation risk on larval gadids by pelagic fish in the Georges Bank ecosystem. I. Spatial overlap associated with hydrographic features. Can J Fish Aquat Sci 57:2455-2469

Gilbert M, Fortier L, Ponton D, Drolet R (1992) Feeding ecology of marine fish larvae across the Great Whale River plume in seasonally ice-covered southeastern Hudson Bay. Mar Ecol Prog Ser 84:19-30

Gilliam JF, Fraser DF (1987) Habitat selection under predation hazard: test of a model with foraging minnows. Ecology 68:1856-1862

Grimm V, Railsback SF (2005) Individual based modeling and ecology. Princeton University Press, Princeton, NJ

Grimm V, Berger U, Bastiansen F, Eliassen S and others (2006) A standard protocol for describing individual-based and agent-based models. Ecol Model 198:115-126

Hare JA, Cowen RK (1997) Size, growth, development, and survival of the planktonic larvae of Pomatomus saltatrix (Pisces: Pomatomidae). Ecology 78:2415-2431

Hjort J (1914) Fluctuations in the great fisheries of northern Europe viewed in the light of biological research. Rapp P-V Reun Cons Int Explor Mer 20:1-228

Holling CS (1966) The functional response of invertebrate predators to prey density. Mem Entomol Soc Can 48: $1-86$

> Holzman R, Genin A (2005) Mechanisms of selectivity in a nocturnal fish: a lack of active prey choice. Oecologia 146: $329-336$

Houde ED (1987) Fish early life dynamics and recruitment variability. Am Fish Soc Symp 2:17-29

Houde ED (1997) Patterns and trends in larval-stage growth and mortality of teleost fish. J Fish Biol 51:52-83

Hunter JR (1981) Feeding ecology and predation of marine fish larvae. In: Lasker R (ed) Marine fish larvae: morphology, ecology, and relation to fisheries. University of Washington Press, Seattle, WA, p 33-77

Kane J (1984) The feeding habits of co-occurring cod and haddock larvae from Georges Bank. Mar Ecol Prog Ser 16:9-20

Kane J (2007) Zooplankton abundance trends on Georges Bank 1977-2004. ICES J Mar Sci 64:909-919

> Kiørboe T, MacKenzie B (1995) Turbulence-enhanced prey encounter rates in larval fish: effects of spatial scale, larval behaviour and size. J Plankton Res 17:2319-2331

Kristiansen T (2007) Modeling early life history of cod. PhD dissertation, University of Bergen, Bergen; http://hdl. handle.net/1956/2190

Kristiansen T, Fiksen $\varnothing$, Folkvord A (2007) Modelling feeding, growth, and habitat selection in larval Atlantic cod (Gadus morhua): observations and model predictions in a macrocosm environment. Can J Fish Aquat Sci 64: $136-151$ 
Lough RG, Mountain DG (1996) Effect of small-scale turbulence on feeding rates of larval cod and haddock in stratified water on Georges-Bank. Deep-Sea Res II 43: 1745-1772

Lough RG, Buckley LJ, Werner FE, Quinlan JA, Edwards KP (2005) A general biophysical model of larval cod (Gadus morhua) growth applied to populations on Georges Bank. Fish Oceanogr 14:241-262

Luo J, Brandt SB, Klebasko MJ (1996) Virtual reality of planktivores: a fish's perspective of prey size selection. Mar Ecol Prog Ser 140:271-283

MacKenzie BR, Kiørboe T (1995) Encounter rates and swimming behavior of pause-travel and cruise larval fish predators in calm and turbulent laboratory environments. Limnol Oceanogr 40:1278-1289

MacKenzie BR, Kiørboe T (2000) Larval fish feeding and turbulence: a case for the downside. Limnol Oceanogr 45 : $1-10$

McGurk MD (1986) Natural mortality of marine pelagic fish eggs and larvae: role of spatial patchiness. Mar Ecol Prog Ser 34:227-242

Miller TJ (2007) Contributions of individual-based coupled physical-biological models to understanding recruitment in marine fish populations. Mar Ecol Prog Ser 347:127-138

Miller TJ, Crowder LB, Rice JA, Marshall EA (1988) Larval size and recruitment mechanisms in fishes: toward a conceptual framework. Can J Fish Aquat Sci 45:1657-1668

Naimie CE (1996) Georges Bank residual circulation during weak and strong stratification periods: prognostic numerical model results. J Geophys Res 101:6469-6486

O'Brien WJ, Evans BI, Browman HI (1989) Flexible search tactics and efficient foraging in salutatory searching animals. Oecologia 80:100-110

Ottersen G, Loeng H (2000) Covariability in early growth and year-class strength of Barents Sea cod, haddock, and herring: the environmental link. ICES J Mar Sci 57:339-348

Peck MA, Buckley LJ, Bengtson DA (2006) Effects of temperature and body size on the swimming speed of larval and

Editorial responsibility: Hans Heinrich Janssen, Oldendorf/Luhe, Germany juvenile Atlantic cod (Gadus morhua): implications for individual-based modelling. Environ Biol Fishes 75:419-429

Pope JG, Sheperd JG, Webb J (1994) Successful surf-riding on size spectra: the secret of survival in the sea. Philos Trans R Soc Lond B Biol Sci 343:41-49

Puvanendran V, Salies K, Laurel B, Brown JA (2004) Sizedependent foraging of larval Atlantic cod (Gadus morhua). Can J Zool 82:1380-1389

Rowlands WLI, Dickey-Collas M, Geffen AJ, Nash RDM (2008) Diet overlap and prey selection through metamorphosis in Irish Sea cod (Gadus morhua), haddock (Melanogrammus eaglefinus), and whiting (Merlangius merlangus). Can J Fish Aquat Sci 65:1297-1306

> Skartveit A, Olseth JA, Tuft ME (1998) An hourly diffuse fraction model with correction for variability and surface albedo. Sol Energy 63:173-183

Sundby S, Bjørke H, Soldal AV, Olsen S (1989) Mortality rates during the early life stages and year-class strength of the Northeast Arctic cod (Gadus morhua L.). Rapp P-V Reun Cons Int Explor Mer 191:351-358

- Tiselius P, Jonsson PR (1990) Foraging behaviour of six calanoid copepods: observations and hydrodynamic analysis. Mar Ecol Prog Ser 66:23-33

Titelman J (2001) Swimming and escape behavior of copepod nauplii: implications for predator-prey interactions among copepods. Mar Ecol Prog Ser 213:203-213

> Titelman J, Kiørboe T (2003) Predator avoidance by nauplii. Mar Ecol Prog Ser 247:137-149

Utne-Palm AC (2000) Prey visibility, activity, size and catchability's (evasiveness) influence on Gobiusculus flavescens prey choice. Sarsia 85:157-165

> Vikebø F, Jørgensen C, Kristiansen T, Fiksen Ø (2007) Drift, growth and survival of larval Northeast Arctic cod with simple rules of behaviour. Mar Ecol Prog Ser 347:207-219

Werner FE, Quinlan JA, Lough RG, Lynch DR (2001) Spatially-explicit individual based modeling of marine populations: a review of the advances in the 1990s. Sarsia 86:411-421

Submitted: October 12, 2007; Accepted: October 24, 2008 Proofs received from author(s): January 30, 2009 